NBER WORKING PAPER SERIES

HEALTH AND ECONOMIC GROWTH:

RECONCILING THE MICRO AND MACRO EVIDENCE

\author{
David E. Bloom \\ David Canning \\ Rainer Kotschy \\ Klaus Prettner \\ Johannes J. Schünemann \\ Working Paper 26003 \\ http://www.nber.org/papers/w26003 \\ NATIONAL BUREAU OF ECONOMIC RESEARCH \\ 1050 Massachusetts Avenue \\ Cambridge, MA 02138 \\ June 2019, Revised June 2022
}

The authors would like to thank participants of the VfS Annual Congress 2018 and the European Meeting of the Econometric Society 2018 and Ana Abeliansky, Michael Burda, Alexander Khoury, Holger Strulik, and Uwe Sunde for helpful comments and suggestions. The views expressed herein are those of the authors and do not necessarily reflect the views of the National Bureau of Economic Research.

NBER working papers are circulated for discussion and comment purposes. They have not been peer-reviewed or been subject to the review by the NBER Board of Directors that accompanies official NBER publications.

(C) 2019 by David E. Bloom, David Canning, Rainer Kotschy, Klaus Prettner, and Johannes J. Schünemann. All rights reserved. Short sections of text, not to exceed two paragraphs, may be quoted without explicit permission provided that full credit, including $(\odot)$ notice, is given to the source. 
Health and Economic Growth: Reconciling the Micro and Macro Evidence

David E. Bloom, David Canning, Rainer Kotschy, Klaus Prettner, and Johannes J. Schünemann NBER Working Paper No. 26003

June 2019, Revised June 2022

JEL No. I15,I25,J11,O11,O15

\begin{abstract}
Economists use micro-based and macro-based approaches to assess the macroeconomic return to population health. The macro-based approach tends to yield estimates that are either negative and close to zero or positive and an order of magnitude larger than the range of estimates derived from the micro-based approach. This presents a micro-macro puzzle regarding the macroeconomic return to health. We reconcile the two approaches by controlling for the indirect effects of health, which macro-based approaches usually include but micro-based approaches deliberately omit when isolating the direct effect of health. Our results show that the macroeconomic return to health lies in the range of plausible microeconomic estimates, demonstrating that both approaches are in fact consistent with one another.

David E. Bloom

Harvard T.H. Chan School of Public Health

Department of Global Health and Population 665 Huntington Ave.

Building 1, Suite 1202

Boston, MA 02115

and IZA

and also NBER

dbloom@hsph.harvard.edu

David Canning

Harvard School of Public Health

Department of Global Health and Population

665 Huntington Ave.

Boston, MA 02115

dcanning@hsph.harvard.edu

Rainer Kotschy

Department of Global Health and Population

Harvard T.H. Chan School of Public Health

665 Huntington Ave

Building 1, Suite 1202

Boston, MA 02115

rkotschy@hsph.harvard.edu

Klaus Prettner

University of Hohenheim

Institute of Economics

Schloss Hohenheim 1d

70593 Stuttgart

Germany

Klaus.prettner@uni-hohenheim.de

Johannes J. Schünemann

University of Fribourg

Bd. de Pérolles 90

1700 Fribourg

Switzerland

johannes.schuenemann@wiwi.uni-goettingen.de
\end{abstract}




\title{
Health and Economic Growth: Reconciling the Micro and Macro Evidence
}

\author{
David E. Bloom ${ }^{a}$, David Canning ${ }^{a}$, Rainer Kotschy ${ }^{a}$, Klaus Prettner ${ }^{b, c}$, Johannes Schünemann ${ }^{d}$ \\ ${ }^{a}$ Harvard T.H. Chan School of Public Health, Harvard University, MA 02115, USA \\ ${ }^{b}$ Department of Economics, Vienna University of Economics and Business, 1020 Vienna, Austria \\ ${ }^{c}$ Wittgenstein Centre for Demography and Global Human Capital, 1030 Vienna, Austria \\ ${ }^{d}$ Department of Economics, University of Fribourg, 1700 Fribourg, Switzerland
}

JEL Codes: I15, I25, J11, O11, O15

Keywords: Productivity, Population Health, Human Capital, Economic Development

\begin{abstract}
Economists use micro-based and macro-based approaches to assess the macroeconomic return to population health. The macro-based approach tends to yield estimates that are either negative and close to zero or positive and an order of magnitude larger than the range of estimates derived from the micro-based approach. This presents a micro-macro puzzle regarding the macroeconomic return to health. We reconcile the two approaches by controlling for the indirect effects of health, which macro-based approaches usually include but micro-based approaches deliberately omit when isolating the direct effect of health. Our results show that the macroeconomic return to health lies in the range of plausible microeconomic estimates, demonstrating that both approaches are in fact consistent with one another.
\end{abstract}

\section{Introduction}

Health is an essential component of human capital that supports worker productivity by enhancing physical capacity and mental capabilities. Health improvements influence economic growth through many pathways: better health increases labor market participation and worker productivity (Strauss and Thomas, 1998; Bloom and Canning, 2002; Schultz, 2002); higher life expectancy creates incentives to invest in education, innovation, and physical capital (Bloom et al., 2003, 2007; Cervellati and Sunde, 2013; Prettner, 2013); and better health, particularly that of women, reduces fertility and spurs an economic transition from a state of stagnating incomes toward sustained 
economic growth (Galor and Weil, 2000; Galor, 2011; Cervellati and Sunde, 2011; Cervellati and Sunde, 2015; Bloom et al., 2020). In contrast, epidemics and pandemics can take an enormous human toll and impose a massive burden on economies (Bloom et al., 2022).

Economists use two methods to assess the macroeconomic return to population health, which measures how much improvements in population health increase economic growth in terms of income per capita or income per worker. Micro-based approaches derive the macroeconomic return to health by aggregating the estimates of Mincerian wage regressions that explain variation in wages by differences in individual health holding other factors constant. Macro-based approaches estimate a generalized aggregate production function that decomposes human capital into its components, including not only population health but also other factors. While most studies based on these methods indicate a positive macroeconomic return to health, the size of the return remains subject to intense debate. In particular, the macro-based approach tends to find estimates that are either negative and close to zero (Caselli et al., 1996; Acemoglu and Johnson, 2007, 2014; Hansen and Lønstrup, 2015) or 2.5 to 18.5 times larger than micro-based estimates (Barro and Lee, 1994; Barro, 1997; Bloom and Williamson, 1998; Gallup and Sachs, 2001; Bloom et al., 2004; Sala-iMartin et al., 2004; Lorentzen et al., 2008; Aghion et al., 2011; Bloom et al., 2014). This presents a micro-macro puzzle of the macroeconomic return to health. On the one hand, the small negative estimates suggest that health is irrelevant or even detrimental to economic development, which seems to conflict with evidence of a positive return of health on economic outcomes at the individual level (Miguel and Kremer, 2004; Bleakley, 2007; Bleakley and Lange, 2009; Field et al., 2009; Baird et al., 2016). On the other hand, the large positive estimates far exceed the macroeconomic return to health that results when aggregating the microeconomic returns to the macro level (Shastry and Weil, 2003; Weil, 2007; Bleakley, 2010). ${ }^{1}$

One might suspect this puzzle emerges because isolating causal pathways from health to income is challenging. This concern especially applies to early contributions, which use cross-sectional variation to compute the macroeconomic return to health. However, even recent contributions that leverage natural experiments and instrumental variables find estimates that are negative or 2.5 to 10 times larger than micro-based estimates. Hence, the discrepancy between micro-based and macro-based estimates of the macroeconomic return to health must have another reason.

This paper aims to reconcile micro-based and macro-based approaches by showing that estimates derived from a well-specified macroeconomic analysis are compatible with estimates based on well-identified microeconomic results. We argue that the gradient between micro-based and macrobased estimates emerges because these approaches measure conceptually different aspects of

${ }^{1}$ Conceptually different work by Kotschy (2021) finds similar positive effects of adult health on income per working-age person across U.S. states using census data to control for population size. For an overview of the estimates for the macroeconomic return to health, see Table A1 in the Appendix. 
the macroeconomic return to health. While micro-based approaches abstract from indirect effects of health on growth (for example through the effect of health on education and saving), macrobased approaches include these indirect effects to estimate the overall effect of health. We overcome this difference by estimating a macro-based model incorporating a Mincerian wage regression that is consistent with the micro-based evidence on the direct effect of health on growth. To this end, we develop a production function model of economic growth, keeping our specification as close as possible to a generalized Mincerian wage equation as proposed by micro-based approaches. This permits us to compare our macro-level estimates and the results from micro-level calibrations directly. This comparison is not possible for other macro-based models in the literature because they lack the conceptual link between the microeconomic and macroeconomic determinants of economic performance through the Mincer equation.

We estimate our macro-based model for 133 countries observed every five years from 1965 to 2015. The specifications use within-country variation of predetermined measures of human capital in a dynamic cross-country panel controlling for past economic development, institutions, demographic structure, and time trends. We show that our results are stable with respect to i) changes in the specification by including country-specific growth trends and additional control variables, ii) changes in the estimation method, and iii) changes in the sample size. All approaches yield similar estimates of the macroeconomic return to health that quantitatively match the wellidentified evidence from the micro-based approach. Moreover, our additional estimates for physical capital, human capital, and convergence all fit the stylized facts in the literature.

According to Weil's (2007) micro-based approach, a 10-percentage-point increase in adult survival rates raises labor productivity by 6.7 or 13.4 percent, depending on the microeconomic estimates used for calibration. Given the conservative estimate of 6.7 percent, health differentials account for about 9.9 percent of the variation in income per worker across countries (Weil, 2007). Our macrobased analysis implies that a 10-percentage-point increase in adult survival rates is associated with a 10.6-percent increase in labor productivity. Weil's estimates fall within the 95-percent confidence interval of our estimate, suggesting that the two models' results are compatible. Likewise, our estimate falls within the interval of values consistent with Weil's micro evidence. Because we include physical capital and education in our empirical framework, the resulting estimate excludes indirect effects such as the role of better health in increasing the incentives for investment, saving, and education, and its role in reducing fertility and spurring a takeoff toward sustained growth. Hence, we can interpret our estimate as a measure of the direct productivity benefits of health as estimated in micro-based approaches.

This paper contributes to the literature in two ways. First, our results show that micro-based and macro-based estimates of the macroeconomic return to health are consistent with one another, once we adopt a conceptually comparable framework. This result justifies using the micro-based 
approach to estimate the direct economic benefits of specific health interventions at the macro level. Second, our results shed new light on the interpretation of the macro-based evidence in the literature. The sizable gradient between the direct effect of health and the total effect of health indicates that health has significant indirect effects on growth. Successful development policies should therefore account for both direct and indirect effects of health interventions by devising complementary policies that also target the indirect effects of health.

\section{The Effect of Health on Economic Growth: From Theory to Empirics}

\subsection{Theoretical Framework}

To derive the direct effects of health on economic growth, we develop a production function model that decomposes human capital into its components, building on a generalized Mincerian wage equation. Assume that time $t=1,2, \ldots, \mathrm{T}$ evolves discretely and consider an aggregate production function of the form

$$
Y_{t}=A_{t} K_{t}^{\alpha} H_{t}^{1-\alpha},
$$

where $Y_{t}$ denotes aggregate output (which is equivalent to aggregate income in a closed economy), $A_{t}$ represents total factor productivity (which represents the economy's technological level), $K_{t}$ is the physical capital stock, $H_{t}$ describes the aggregate human capital stock, and $\alpha$ constitutes the elasticity of aggregate income with respect to physical capital. The specifications in the macroeconomic literature rely on a production function with constant returns to scale, such that a comparison between our results and the various macro-based estimates requires us to do the same. The sum of individual levels of human capital $v_{j, t}$ of workers $j=1,2, \ldots, J$ in the economythat is, $H_{t}=\sum_{j}^{J} v_{j, t}$-describes the aggregate stock of human capital. Expressing income in per worker units and per capita units yields (2) and (3):

$$
\begin{gathered}
y_{t}=A_{t} k_{t}^{\alpha} v_{t}{ }^{1-\alpha}, \\
\tilde{y}_{t}=\frac{Y_{t}}{N_{t}}=\frac{L_{t}}{N_{t}} A_{t} k_{t}^{\alpha} v_{t}{ }^{1-\alpha},
\end{gathered}
$$

where $L_{t}$ refers to the size of the workforce, $N_{t}$ to the total population size, and $v_{t}$ to the average human capital stock of workers.

In a competitive labor market, one unit of composite labor $v_{t}$ earns the wage $w_{t}$, which equals its marginal product: ${ }^{2}$

\footnotetext{
${ }^{2}$ This holds under the assumption that a marginal change of individual human capital does not change the distribution of wages such that the marginal product of individual human capital and that of average human capital coincide.
} 


$$
w_{t}=\frac{\partial \tilde{y}_{t}}{\partial v_{t}}=(1-\alpha) \frac{\tilde{y}_{t}}{v_{t}}
$$

Furthermore, individual human capital follows a generalized Mincerian wage equation along the lines of Hall and Jones (1999), Bils and Klenow (2000), and Weil (2007). Hence, individual human capital $v_{j, t}$ follows an exponential function:

$$
v_{j, t}=\exp \left(\phi_{h} h_{j, t}+\phi_{s} s_{j, t}\right)
$$

where $h_{j, t}$ denotes the state of health, $s_{j, t}$ denotes educational attainment, $\phi_{h}$ is the semi-elasticity of human capital with respect to health, and $\phi_{S}$ is the semi-elasticity of human capital with respect to educational attainment. Conceptually, $h_{j, t}$ and $s_{j, t}$ need not represent all aspects of health and educational attainment, only those that are relevant to produce final output. We also consider an augmented version of this model in which we add experience and experience squared to account for a positive but diminishing marginal return to experience. As we show subsequently, however, including experience does not significantly alter the estimated macroeconomic return to health. Accordingly, a worker $j$ with $v_{j}$ units of human capital earns a wage of

$$
w_{j, t}=w_{t} \cdot v_{j, t}=w_{t} \cdot \exp \left(\phi_{h} h_{j, t}+\phi_{s} s_{j, t}\right)
$$

This notation normalizes the effective labor input of a hypothetical worker without any health capital and education to one. Meanwhile, workers with better health and higher education are equivalent in productivity to more such baseline workers. Logarithmic wages at the individual level thus take the well-known Mincerian form:

$$
\ln \left(w_{j, t}\right)=\ln \left(w_{t}\right)+\ln \left(v_{j, t}\right)=\ln \left(w_{t}\right)+\phi_{h} h_{j, t}+\phi_{s} s_{j, t}
$$

Hence, the aggregate production function in (1) with our measure for human capital in (4) is consistent with wage equations used in the microeconomic literature.

The Mincerian wage form implies that the aggregate human capital stock is given by

$$
H_{t}=\sum_{j}^{\mathcal{J}} v_{j, t}=\sum_{j}^{\mathcal{J}} \exp \left(\phi_{h} h_{j, t}+\phi_{s} s_{j, t}\right)
$$

Aggregating human capital requires exponentiating a standard function of individuals' health and educational attainment. This complication in the aggregation vanishes if human capital and thus wages follow a log-normal distribution. In this case, the log of the average wage corresponds to the average of log wages plus one-half of the variance of log wages $\sigma_{t}^{2}$. Therefore, the log of human capital per worker simplifies to 


$$
\begin{aligned}
\ln \left(\frac{H_{t}}{L_{t}}\right)=\ln \left(\frac{\sum_{j}^{\mathcal{J}} v_{j, t}}{L_{t}}\right) & =\frac{\left[\sum_{j}^{\mathcal{J}} \ln \left(v_{j, t}\right)\right]}{L_{t}}+\frac{\sigma_{t}^{2}}{2} \\
& =\frac{\sum_{j}^{\mathcal{J}} \phi_{h} h_{j, t}+\phi_{s} s_{j, t}}{L_{t}}+\frac{\sigma_{t}^{2}}{2} \\
& =\phi_{h} h_{t}+\phi_{s} s_{t}+\frac{\sigma_{t}^{2}}{2}
\end{aligned}
$$

In this framework, a marginally better health status (for example, an increase in the adult survival rate by 1 percentage point) raises labor productivity and wages by $100 \cdot \phi_{h}$ percent. Analogously, additional marginal investment in education (for example, one year of schooling) raises labor productivity and wages by $100 \cdot \phi_{s}$ percent. This effect's absolute size is larger for highly educated high-wage workers than for poorly educated low-wage workers. Moreover, an extra year of education for a highly educated worker also represents a greater investment because the worker forgoes a higher wage for extra schooling.

\subsection{Empirical Framework}

Suppose the production function in (3) applies to $i=1, \ldots, I$ countries. Taking the logarithm of the production function and using the result from (8), the log of income per capita is given by

$$
\ln \left(\tilde{y}_{i, t}\right)=\ln \left(\frac{L_{i, t}}{N_{i, t}}\right)+\ln \left(A_{i, t}\right)+\alpha \ln \left(k_{i, t}\right)+(1-\alpha)\left(\phi_{h} h_{i, t}+\phi_{s} s_{i, t}+\frac{\sigma_{i, t}^{2}}{2}\right) .
$$

In equation (9) income per capita could be estimated directly if all right-hand-side variables were available. In practice, however, total factor productivity is not observed. Several approaches can address this problem. We follow Bloom et al. (2004) and model technological development as a diffusion process across countries, which allows for the possibility of long-run differences in total factor productivity even after the diffusion is complete. The change in total factor productivity is then given by

$$
\Delta \ln \left(A_{i, t}\right)=\lambda\left[\ln \left(A_{i, t}^{*}\right)-\ln \left(A_{i, t-1}\right)\right]+\varepsilon_{i, t}
$$

where $\varepsilon_{i, t}$ constitutes an idiosyncratic shock to technological development. Each country has a period-specific upper bound, given by $\ln \left(A_{i, t}^{*}\right)$. A country's total factor productivity adjusts toward this bound at rate $\lambda$. We assume this upper bound depends on country characteristics $x_{i, t}$ and on the worldwide technology frontier $\mu_{t}$. Moreover, schooling in previous periods may facilitate the diffusion and adoption of existing technologies (Nelson and Phelps, 1966) or spur novel innovation (Romer, 1990; Strulik et al., 2013). Hence, lagged schooling $s_{i, t-1}$ constitutes another determinant of potential total factor productivity. Neglecting one of these channels might bias the empirical 
estimates, as Sunde and Vischer's (2015) results indicate. Because technological gaps are not directly observed, we follow Baumol (1986) and use lagged income per capita as a proxy (see also Fagerberg, 1994; Dowrick and Rogers, 2002). Hence, technological development is given by

$$
\Delta \ln \left(A_{i, t}\right)=\lambda\left[\mu_{t}+x_{i, t}{ }^{\prime} \Theta+\rho s_{i, t-1}-\ln \left(\tilde{y}_{i, t-1}\right)\right]+\varepsilon_{i, t}
$$

Alternatively, a richer model derives the log of lagged total factor productivity $\ln \left(A_{i, t-1}\right)$ directly from the production function such that

$$
\begin{aligned}
\Delta \ln \left(A_{i, t}\right)=\lambda\left[\mu_{t}\right. & \left.+x_{i, t}^{\prime} \Theta+\rho s_{i, t-1}-\ln \left(\tilde{y}_{i, t-1}\right)+\alpha \ln \left(k_{i, t-1}\right)\right]+\lambda(1-\alpha)\left(\phi_{h} h_{i, t-1}+\phi_{s} s_{i, t-1}+\frac{\sigma_{i, t-1}^{2}}{2}\right) \\
& +\varepsilon_{i, t} .
\end{aligned}
$$

This slightly more comprehensive modeling approach, however, suffers from including additional highly correlated explanatory variables that inflate the estimated standard errors without providing additional insights into the parameters of interest. We provide estimates for both models and show that they are qualitatively and quantitatively similar.

First-differencing (9) and inserting (11) provides our estimation equation:

$$
\begin{gathered}
\Delta \ln \left(\tilde{y}_{i, t}\right)=\Delta \ln \left(\frac{L_{i, t}}{N_{i, t}}\right)+\lambda\left[\mu_{t}+x_{i, t}^{\prime} \Theta+\rho s_{i, t-1}-\ln \left(\tilde{y}_{i, t-1}\right)\right]+\alpha \Delta \ln \left(k_{i, t}\right) \\
+(1-\alpha)\left(\phi_{h} \Delta\left(h_{i, t}\right)+\phi_{s} \Delta\left(s_{i, t}\right)+\frac{\Delta\left(\sigma_{i, t}^{2}\right)}{2}\right)+\varepsilon_{i, t} .
\end{gathered}
$$

According to this specification, growth of income per capita $\Delta \ln \left(\tilde{y}_{i, t}\right)$ can be decomposed into four components. The first component represents growth of the working-age population relative to the total population, which converts the model from per worker into per capita units according to (3). The second component is a catch-up term that captures the reduction of the technological gap between country $i$ and the leading countries in each time period. The catch-up speed depends on the convergence rate $\lambda$, the world technology frontier $\mu_{t}$, country-specific characteristics $x_{i, t}$, and past levels of education $s_{i, t-1}$ and income $\ln \left(\tilde{y}_{i, t-1}\right)$. The third component comprises growth of capital per worker $\Delta \ln \left(k_{i, t}\right)$, changes in the input factors health $\Delta\left(h_{i, t}\right)$ and education $\Delta\left(s_{i, t}\right)$, and the change in wage dispersion $\Delta\left(\sigma_{i, t}^{2}\right)$ that arises when aggregating human capital. The fourth component is an idiosyncratic shock $\varepsilon_{i, t}$ to the country's technological development. 
When estimating our model, changes in input factors might repond to technological shocks $\varepsilon_{i, t}$. We address this concern in several ways. First, we use within-country variation of predetermined measures of human capital in a dynamic cross-country panel controlling for past economic development, institutions, demographic structure, and time trends. Specifically, we measure changes in health and education of the working-age population, which reflect changes in potential health and education inputs of the workforce rather than actual workforce health and education inputs, which might react sensitively to variations in labor supply. In additional specifications, we also include country-specific growth trends, lagged input factors, population growth, geography, trade, and ethnic fractionalization to account for unobserved heterogeneity with a persistent effect on technological development.

Second, we take advantage of the data's time structure to estimate the parameters via dynamic panel generalized method of moments (GMM) models, thereby eliminating potential correlations that arise mechanically through a link between the lagged dependent variable and technology shocks in the error term. Specifically, this approach instruments potentially endogenous regressors by their lagged values, thereby also accounting for a reverse effect from income growth to changes in population health.

Third, we assess the stability of our results with respect to changes in the sample composition and the sample length. This exercise addresses concerns regarding result heterogeneity with respect to economic development, institutional environment, and period-specific events. Moreover, these specifications serve as a robustness test: if changes in input factors were to respond to countryperiod-specific technology shocks, obtaining systematically similar results across different samples and time periods would be unlikely.

\subsection{Data}

We estimate our equation for 133 countries observed every five years over the period 1965-2015. Data on income and physical capital are from the Penn World Tables (Feenstra et al., 2015).

Health measures are obtained from United Nations (2017). We use adult survival rates, which measure the probability of surviving from age 15 to 60 . We use this measure to compare our results directly with those of Weil's (2007) micro-based approach. Conceptually, this measure may relate more closely to adult health and worker productivity than life expectancy, which is sensitive to changes in infant mortality rates. We report results for an alternative specification using life expectancy in the robustness section. However, both adult survival rates and life expectancy are only proxies for workforce health because they measure mortality rates rather than morbidity.

The mean of the adult survival rate in the sample is 0.8 , which implies that the average probability of surviving from age 15 to 60 across all countries and periods is 80 percent. To get an idea of the 
variation in survival rates, consider an increase in the adult survival rate of 10 percentage pointsour measure for interpreting the effect of population health on labor productivity. Between 1970 and 2015 , adult survival rates rose on average by 10 percentage points (from 0.7 to 0.8 ) in nonadvanced economies and by 8 percentage points (from 0.84 to 0.92 ) in advanced economies.

Data on education are obtained from Barro and Lee (2013). We proxy education by years of secondary schooling for the working-age population 15-64. We focus on secondary schooling because it accounts for most of the variation in education in our sample and provide results for total years of schooling in the Appendix.

In extended specifications, we augment the modeling of human capital with respect to experience. To this end, we construct experience as the median age of the population (United Nations, 2017) net of the labor market entry age as measured by an intercept of six years corresponding to early childhood plus years of compulsory schooling (UNESCO, 1963-1997, 2017). This correction is necessary because countries with higher life expectancy and older populations tend to have later workforce entry due to longer schooling. As experience enters the regression framework in differences, this measure takes up variation from changes in median age and compulsory schooling following educational reforms. ${ }^{3}$ In additional extended specifications, we approximate changes in wage dispersion by changes in income inequality. We measure inequality by pre-tax, pre-transfer income Gini coefficients (Solt, 2020), which are standardized and thus comparable across countries and over time. We do not include experience and inequality in the baseline specification, as this reduces the sample size by up to 340 observations without improving the model's explanatory power and does not change the main findings considerably.

We also control for variables that might affect a country's technological development. Specifically, we add time effects for the world technology frontier and country-specific controls for institutional quality (Gwartney et al., 2017). Institutional quality is particularly important, as it may simultaneously raise income growth, health outcomes, and education (Weil, 2014). Because our models include lagged variables and because the data on institutional quality are available only from 1960 onward, they restrict the estimation sample to the time period 1965-2015.

In robustness tests, we add further controls for population growth (United Nations, 2017); geography in terms of tropical land area and land area within $100 \mathrm{~km}$ of a coast, both measured as a share of the country's territory (Gallup et al., 1999); trade openness, defined as the ratio of imports

${ }^{3}$ For certain countries, the United Nations Educational, Scientific and Cultural Organization's statistical yearbooks (UNESCO, 1963-1997) report values for specific regions. Moreover, some countries' education systems allow for different categorizations, such that alternative figures are conceivable. We correct for these fluctuations and code less-varying values when in doubt. This procedure tends to render the experience measure less informative and thus increases the corresponding standard errors. Table B1 contains a complete list of coding decisions. 
and exports relative to gross domestic product (Feenstra et al., 2015); and cultural heterogeneity in terms of ethnic fractionalization (Alesina et al., 2003).

Table A2 in the Appendix reports descriptive statistics for the estimation sample, and Table A3 lists all countries in the sample.

\section{The Estimated Macroeconomic Return to Health}

Table 1 presents estimation results for the macroeconomic return to health. Specification (1) reports estimates of the baseline model, which are derived from ordinary least squares. The estimates show the signs expected from theory. Lagged income per worker negatively relates to growth, which implies conditional convergence across countries as predicted by growth theory (Solow, 1956; Cass, 1965) and as established empirically (Caselli et al., 1996; Barro, 1997; Sala-i-Martin et al., 2004; Islam, 1995; Durlauf et al., 2005). In turn, capital accumulation positively relates to growth, again conforming to the literature's results. Changes in human capital positively affect income per capita: the estimates for changes in adult survival and in secondary schooling both have a positive sign. Hence, health and education both constitute important dimensions of human capital. All estimates differ from zero at conventional significance levels.

Further specifications show that these results are stable to extensions of the baseline model with respect to additional controls and country-specific growth trends. Specification (2) augments the modeling of human capital with experience and experience squared to account for a positive but diminishing return to worker experience. The corresponding estimates show similar influences of physical and human capital on growth based on a reduced sample of 948 observations. In contrast, the coefficients for experience are small and statistically insignificant (see Table A4 in the Appendix for the coefficients of all control variables). Because experience varies strongly across individuals but little across countries, obtaining a precise estimate of the macroeconomic return to worker experience is difficult (Bloom et al., 2004). Specification (3) controls for changes in income inequality to approximate dynamics in wage disperson over time. The sample shrinks to 731 observations because of data availability. ${ }^{4}$ Again, the estimates take similar values as in the baseline specification and confirm our qualitative findings.

\footnotetext{
${ }^{4}$ When estimating this specification, we conduct a standard-error adjustment. Specifically, we estimate specification (3) for 100 potential realizations of the Gini coefficient and compute the final estimates by averaging all individual results. The reason for this adjustment is that Solt (2020) uses imputation procedures to reduce the number of missing values in the inequality data. This procedure understates the data uncertainty and can thus lead to downward-biased estimates of standard errors (Solt, 2020).
} 
Table 1. Estimated Macroeconomic Return to Health

\begin{tabular}{|c|c|c|c|c|c|c|}
\hline \multirow[t]{2}{*}{ Dependent variable } & \multicolumn{6}{|c|}{ Growth rate of income per capita } \\
\hline & $\begin{array}{c}\text { Baseline } \\
\text { controls } \\
\text { (1) }\end{array}$ & $\begin{array}{c}\text { Including } \\
\text { working } \\
\text { experience } \\
(2)\end{array}$ & $\begin{array}{c}\text { Including } \\
\text { income } \\
\text { inequality } \\
(3)\end{array}$ & $\begin{array}{c}\text { Including } \\
\text { lagged } \\
\text { controls } \\
(4)\end{array}$ & $\begin{array}{l}\text { Country } \\
\text { growth } \\
\text { trends } \\
(5)\end{array}$ & $\begin{array}{c}\text { Panel } \\
\text { GMM } \\
(6)\end{array}$ \\
\hline Log income per capita $(t-1)$ & $\begin{array}{c}-0.070^{* * *} \\
(0.009)\end{array}$ & $\begin{array}{c}-0.071^{* * *} \\
(0.009)\end{array}$ & $\begin{array}{c}-0.073^{* * *} \\
(0.011)\end{array}$ & $\begin{array}{c}-0.158^{* * *} \\
(0.014)\end{array}$ & $\begin{array}{c}-0.270^{* * *} \\
(0.034)\end{array}$ & $\begin{array}{c}-0.060^{* * *} \\
(0.023)\end{array}$ \\
\hline Growth of capital per worker & $\begin{array}{c}0.344^{* * *} \\
(0.049)\end{array}$ & $\begin{array}{c}0.355^{* * *} \\
(0.048)\end{array}$ & $\begin{array}{c}0.284^{* * *} \\
(0.058)\end{array}$ & $\begin{array}{c}0.343^{* * *} \\
(0.059)\end{array}$ & $\begin{array}{c}0.257^{* * *} \\
(0.082)\end{array}$ & $\begin{array}{c}0.364^{* * *} \\
(0.051)\end{array}$ \\
\hline Change in adult survival & $\begin{array}{c}0.698^{* * *} \\
(0.258)\end{array}$ & $\begin{array}{c}0.899^{* * *} \\
(0.238)\end{array}$ & $\begin{array}{c}0.792^{* * *} \\
(0.301)\end{array}$ & $\begin{array}{c}0.694^{* * *} \\
(0.253)\end{array}$ & $\begin{array}{l}0.394^{*} \\
(0.220)\end{array}$ & $\begin{array}{c}0.653^{* *} \\
(0.271)\end{array}$ \\
\hline Change in secondary schooling & $\begin{array}{c}0.068^{* * *} \\
(0.024)\end{array}$ & $\begin{array}{c}0.065^{* * *} \\
(0.024)\end{array}$ & $\begin{array}{c}0.057^{* *} \\
(0.023)\end{array}$ & $\begin{array}{c}0.030 \\
(0.023)\end{array}$ & $\begin{array}{l}0.049^{*} \\
(0.026)\end{array}$ & $\begin{array}{r}0.062^{* *} \\
(0.028)\end{array}$ \\
\hline $\begin{array}{l}\text { Growth of working-age population/ } \\
\text { total population }\end{array}$ & $\begin{array}{c}1.043^{* * *} \\
(0.306)\end{array}$ & $\begin{array}{c}1.051^{* * *} \\
(0.345)\end{array}$ & $\begin{array}{c}0.989^{* *} \\
(0.405)\end{array}$ & $\begin{array}{c}0.983^{* * *} \\
(0.291)\end{array}$ & $\begin{array}{c}0.231 \\
(0.415)\end{array}$ & $\begin{array}{c}0.968^{* * *} \\
(0.361)\end{array}$ \\
\hline Countries & 133 & 131 & 131 & 133 & 133 & 133 \\
\hline Observations & 1020 & 948 & 731 & 1020 & 1020 & 1020 \\
\hline$R^{2}$ & 0.29 & 0.30 & - & 0.34 & 0.33 & - \\
\hline $\mathrm{AR}(2) p$-value & - & - & - & - & - & 0.10 \\
\hline Hansen $p$-value & - & - & - & - & - & 0.15 \\
\hline Diff.-in-Hansen $p$-value & - & - & - & - & - & 0.97 \\
\hline
\end{tabular}

Note: Estimation results for five-year panels of 133 countries over the period 1965-2015. Estimates are derived from ordinary least squares in specifications (1) to (5) and system GMM in (6). All specifications include time fixed effects, controls for lagged years of secondary schooling, and quality of economic institutions. Specification (2) includes controls for experience and experience squared; specification (3) includes the pre-tax, pre-transfer Gini coefficient; and specification (4) includes lagged controls for physical capital per worker, population health, and the size of the working-age population relative to the total population. Specifications in (5) and (6) account for country-specific growth trends by including country-fixed effects. The panel GMM specification in (6) uses the first lag of the endogenous variables in the difference equation and the first difference of the endogenous variables in the level equation as instruments; standard errors in this specification are computed with the two-step procedure and corrected with respect to finite sample size (Windmeijer, 2005). Standard errors are clustered at the country level and reported in parentheses. Asterisks indicate significance levels: * $p<0.1 ;{ }^{* \star} p<0.05 ;{ }^{* \star} p<0.01$.

Specification (4) presents results for a comprehensive model, which derives lagged total factor productivity directly from the production function according to equation (12). This specification includes lagged controls for physical capital per worker, population health, and the size of the working-age population relative to the total population. The estimated coefficients for the adult survival rate resemble those for the baseline specification. Specification (5) contains countryspecific growth trends, which take up unobserved heterogeneity that persistently affects technological development. This specification is more restrictive than the previous models because it relies only on variation in the deviations of input factors from their long-run growth trends. The estimates shrink slightly in size but are still reasonably close to the baseline results.

Another way to assess the results' stability is to exploit the data's time structure to estimate a dynamic panel GMM model to eliminate potential correlations between lagged income per capita, changes in input factors, and technology shocks in the error term. Specifically, we estimate a system GMM model (Arellano and Bover, 1995; Blundell and Bond, 1998), in which we instrument 
lagged income per capita, growth of capital per worker, and changes in adult survival and in secondary schooling by their first lag. Specification (6) in Table 1 reports the corresponding estimates. The coefficients resemble the baseline estimates and confirm the qualitative findings. By relying on lagged variation in the variables, this specification accounts for a potential reverse effect from income growth to changes in population health. ${ }^{5}$ The AR(2) test shows no second-order autocorrelation in the nondemeaned error terms, and the Hansen J-test does not reject the null hypothesis that the instrument set is exogenous.

In addition to these different specifications, the coefficients for growth of the working-age population relative to the total population provide an internal specification test. By construction, these coefficients should not differ from one. None of the coefficients is significantly different from one, and they are all close to one except for the imprecisely estimated coefficient accounting for countryspecific growth trends. This imprecision is unsurprising as the demographic structure changes only slowly and shows little variation above and beyond its long-run growth trends. ${ }^{6}$

A common concern regarding the macro-based approach is that decomposing production functions into their components might produce results that react sensitively to the sample composition both in the cross-sectional and in the time dimension. Table 2 addresses this concern, where we assess the stability of the results with respect to changes in the sample size and sample length.

While specification (1) shows the baseline results for the full sample of 133 countries, specification (2) reproduces the estimation for a balanced sample of 50 countries for which we have data over all 10 time periods after differencing and lagging. Because of data availability, the balanced sample is predominantly predicated upon advanced economies. Irrespective of the considerable change in the composition of countries and the reduction in the number of observations, the coefficients of all explanatory variables take similar values as in the baseline specification and remain statistically significant. In specification (3), we focus on developing and emerging countries and exclude all advanced economies. The coefficient of the adult survival rate has again a similar value as in the baseline specification, whereas the return to secondary schooling grows somewhat in size. Many socialist countries have undergone major social and economic transformations that considerably affected economic development and population health-for example, in the Russian Federation after the collapse of the Soviet Union. To account for the possibility that these countries drive our results, we exclude all countries that previously were or still are socialist in specification (4). Again, the results are quantitatively similar to our main results. Finally, specifications (5) and (6) reduce

\footnotetext{
${ }^{5}$ In the spirit of a reduced form, we also estimated a specification in which we used lagged differences in capital per worker, adult survival rates, and secondary schooling rather than contemporaneous differences. These specifications produced qualitatively similar results with an estimated coefficient for adult survival rates of approximately one half.

${ }^{6}$ To test whether the results in specification (5) hinge on the variation in demographic structure, we estimated a specification in which we imposed a coefficient of one and deducted the variable from the dependent variable. The results confirmed the qualitative findings and showed a slightly larger coefficient for the adult survival rate.
} 
the observation period to 1965-2005 and 1975-2015, respectively. When excluding later time periods, the coefficient estimate of the adult survival rate increases slightly. A potential explanation is that health improvements in later periods predominantly promoted older workers' health, such that the macroeconomic return to health increases when excluding them. Nevertheless, excluding certain time periods still produces results that are quantitatively similar to those of the full-length sample.

Table 2. Stability of Estimates Across Samples and Over Time

\begin{tabular}{lcccccc}
\hline Dependent variable & \multicolumn{5}{c}{ Growth rate of income per capita } \\
\cline { 2 - 7 } & $\begin{array}{c}\text { Full } \\
\text { sample }\end{array}$ & $\begin{array}{c}\text { Balanced } \\
\text { sample }\end{array}$ & $\begin{array}{c}\text { Excluding } \\
\text { advanced } \\
\text { economies }\end{array}$ & $\begin{array}{c}\text { Excluding } \\
\text { socialist } \\
\text { countries }\end{array}$ & $\begin{array}{c}\text { Sample } \\
1965-2005\end{array}$ & $\begin{array}{c}\text { Sample } \\
1975-2015\end{array}$ \\
& $(1)$ & $(2)$ & $(3)$ & $(4)$ & $(5)$ & $(6)$ \\
\hline Log income per capita $(t-1)$ & $-0.070^{* * *}$ & $-0.054^{* * *}$ & $-0.080^{* * *}$ & $-0.061^{* * *}$ & $-0.064^{* * *}$ & $-0.072^{* * *}$ \\
& $(0.009)$ & $(0.018)$ & $(0.011)$ & $(0.011)$ & $(0.011)$ & $(0.009)$ \\
Growth of capital per worker & $0.344^{* * *}$ & $0.322^{* * *}$ & $0.336^{* * *}$ & $0.359^{* * *}$ & $0.313^{* * *}$ & $0.330^{* * *}$ \\
& $(0.049)$ & $(0.069)$ & $(0.056)$ & $(0.056)$ & $(0.060)$ & $(0.051)$ \\
Change in adult survival & $0.698^{* * *}$ & $0.719^{* * *}$ & $0.639^{* *}$ & $0.663^{* *}$ & $0.976^{* * *}$ & $0.685^{* * *}$ \\
& $(0.258)$ & $(0.244)$ & $(0.272)$ & $(0.284)$ & $(0.312)$ & $(0.261)$ \\
Change in secondary schooling & $0.068^{* * *}$ & $0.058^{* *}$ & $0.095^{* * *}$ & $0.080^{* * *}$ & $0.080^{* *}$ & $0.071^{* * * *}$ \\
& $(0.024)$ & $(0.027)$ & $(0.037)$ & $(0.026)$ & $(0.032)$ & $(0.025)$ \\
Growth of working-age population/ & $1.043^{* * *}$ & $1.614^{* * *}$ & $1.083^{* * *}$ & $1.097^{* * *}$ & $1.190^{* * *}$ & $1.100^{* * *}$ \\
total population & $(0.306)$ & $(0.505)$ & $(0.385)$ & $(0.336)$ & $(0.361)$ & $(0.317)$ \\
\hline Countries & 133 & 50 & 98 & 103 & 123 & 133 \\
Observations & 1020 & 500 & 700 & 868 & 756 & 970 \\
$R^{2}$ & 0.29 & 0.31 & 0.33 & 0.26 & 0.26 & 0.28 \\
\hline
\end{tabular}

Note: Results for different samples. Estimates are derived from ordinary least squares. Specification (1) reports results for the unbalanced full sample, whereas specification (2) reports results for the subset of countries that are observed in all periods from 1960 to 2015. Specifications (3) and (4) exclude advanced economies or countries that were or still are socialist. Specifications (5) and (6) report results for shortened samples over the periods 1965-2005 and 1975-2015. All specifications include time fixed effects, controls for lagged years of secondary schooling, and quality of economic institutions. Standard errors are clustered at the country level and reported in parentheses. Asterisks indicate significance levels: ${ }^{*} p<0.1 ;{ }^{* *} p<0.05 ;{ }^{* * *} p<0.01$.

\section{Consistency of Micro-Based and Macro-Based Estimates}

How do these estimates relate to the microeconomic evidence in the literature? Table 3 compares the results of our baseline specification with those of Weil's micro-based approach (2007). Weil derives the macroeconomic return to health using microeconomic estimates of the return on height from childhood inputs, twin studies, and long-run historical data. According to his baseline calibration, an increase in adult survival rates of 0.1 - or 10 percentage points—raises labor productivity by 6.7 percent. To obtain this figure, he uses the two lowest but arguably best-identified estimates at his disposal, stemming from twin studies in the developed world. These estimates are conservative insofar as "[...] nutrition primarily affects physical capabilities and [...] these capabilities are less important in rich than in poor countries [...]" (Weil, 2007, p. 1288). Averaging 
over all estimates and study types would suggest a larger return on labor productivity of 13.4 percent. ${ }^{7}$ We deem values between 6.7 and 13.4 percent to be plausible. Our baseline estimate falls in this range: an increase in adult survival rates of 0.1 translates into a 10.6-percent increase in labor productivity $\left(0.1 \cdot \phi_{h} \approx 0.1 \cdot 0.698 / 0.656 \approx 0.106\right)$. To obtain this figure, we need to divide the estimate of $(1-\alpha) \cdot \phi_{h} \approx 0.698$ in Table 1 by $(1-\alpha) \approx 0.656$, see equation (13). The results do not change substantially when computing this value for the alternative specifications in Table 1 (see Table A5 in the Appendix). The 95-percent confidence interval of our estimate ranges from 3.4 to 17.9 percent and accounts for uncertainty in the macroeconomic return to health that derives from dividing by $(1-\alpha)$, which we estimate. The confidence interval includes the calibrated macroeconomic return to health based on Weil's micro evidence. Likewise, our estimate falls in the range of plausible values implied by Weil's micro-based calibrations. Hence, macro-based and micro-based results are quantitatively similar, implying that micro-based and macro-based approaches to estimating the macroeconomic return to health are consistent with one another after all.

Table 3. Comparison of Our Estimates with the Evidence in the Literature

\begin{tabular}{lccc}
\hline Parameter & Estimate & Confidence interval & Evidence in literature \\
\hline$\lambda$ & $<0$ & - & $<0$ \\
$\alpha$ & 0.34 & $0.25-0.44$ & $0.3-0.4$ \\
$\phi_{h}$ & $10.6 \%$ & $3.4 \%-17.9 \%$ & $6.7 \%-13.4 \%$ \\
$\phi_{s}$ & $10.4 \%$ & $3.5 \%-17.3 \%$ & $9.7 \%$ \\
\hline
\end{tabular}

Note: This table reports parameter estimates for the baseline specification (1) in Table 1. Estimates for the macroeconomic returns to health $\phi_{h}$ and schooling $\phi_{s}$ are obtained by dividing the estimates by $(1-\alpha)$, where $\alpha$ is the estimate of growth in capital per worker. The macroeconomic return to health $\phi_{h}$ is multiplied by 10 to match a 10-percentage-point increase in the adult survival rate. The parameter $\lambda$ denotes convergence in income per worker.

Notably, our confidence interval excludes the point estimates from other macro-based approaches for which we were able to compute the macroeconomic return to health (see Table A1 in the Appendix). This result demonstrates the conceptual and quantitative differences between microbased and macro-based approaches that this paper addresses. We are able to reconcile the microbased and the macro-based estimates because we control for a wide range of indirect effects that health has on other domains, which the micro-based approach disregards by design and which other macro-based approaches include to estimate the total effect of health. For example, i) better health may improve education outcomes of children, ii) better health may imply stronger incentives to save and invest in innovative projects, iii) a society with a better health status may have more incentives to establish inclusive institutions, iv) fertility of healthy women may be lower than fertility

\footnotetext{
${ }^{7}$ Using only Weil's largest estimates—which are predicated on childhood inputs in developing countries—would imply a maximum increase of 17.5 percent in labor productivity.
} 
of unhealthy women with positive repercussions on per capita income growth, v) a better health status of the workforce may facilitate technology adoption, and vi) societies with better health may have undergone the demographic transition earlier. Our framework controls for these channels and thus reduces the potential ways in which indirect health effects influence economic growth. While we cannot control for the indirect effects of immunization with respect to the spread of communicable diseases, the pathways by which these indirect effects could possibly affect productivity growth are widely controlled for as argued previously.

Overall, the consistency between the micro-based and macro-based approaches is reassuring because it would be highly implausible if our macro-based estimates were biased but simultaneously consistent with the micro-based estimates and stable across specifications, estimation methods, and samples. Moreover, our estimates also match the stylized facts of the empirical literature on the remaining explanatory variables. The estimate for growth of capital per worker $\alpha$ is 0.344 . This value is in line with estimates of the elasticity of income with respect to physical capital, which are around 0.3 to 0.4 (Hall and Jones, 1999). Dividing our estimate of education by $(1-\alpha)$ yields a macroeconomic return to secondary schooling of 10.4 percent $\left(\phi_{s} \approx\right.$ $0.068 / 0.656 \approx 0.104)$. This value is consistent with the range of plausible estimates in the literature reviewed in Psacharopoulos and Patrinos (2018), where the return on secondary schooling averages 9.7 percent in 224 studies across 70 countries between 1960 and 2014. Finally, the sign of our estimate on the convergence rate $\lambda$ accords with previous findings on conditional convergence.

\section{Robustness}

This section presents the results' robustness to including additional controls; using different measures of income, health, and education; and to using alternative GMM specifications.

\subsection{Additional Controls}

A potential concern is that other factors not contained in our model may correlate with both economic development and population health. Table A6 in the Appendix presents results for extended specifications that include additional variables suggested by the literature that might affect a country's development. These specifications control for heterogeneity with respect to population growth, trade openness, geography, and ethnic fractionalization in addition to our baseline controls that capture past changes in economic performance, convergence in technology, and country differences in demographic structure and institutions. The corresponding estimates confirm the macroeconomic return to health from our main specification qualitatively and quantitatively. While geography, fractionalization, and to a lesser extent population growth correlate 
with economic development, including these variables neither significantly changes the explanatory variables' coefficients nor improves the model's fit.

\subsection{Income per Worker}

Table A7 in the Appendix reports results for the growth rate of income per worker as the dependent variable instead of the growth rate of income per capita. In these specifications, we transform the dependent variable into per worker by removing the control for growth of the support ratio $\Delta \ln \left(L_{i, t} / N_{i, t}\right)$, thereby following the derivation of our model in equations (2) and (3). The estimated macroeconomic return to health is quantitatively similar to the main results.

\subsection{Life Expectancy at Birth}

Table A8 presents results for empirical specifications in which we proxy health by life expectancy at birth instead of the adult survival rate. The estimates qualitatively confirm the empirical patterns in the main results. Using the correlation between adult survival and life expectancy in our sample, we can quantitatively compare the results for both health measures. The estimates for life expectancy are 1.8 times larger than those for adult survival. However, these estimates are not significantly different from one another. Moreover, both estimates differ from the various estimates of the macroeconomic return to health in the literature that are either negative and close to zero or positive and large. This evidence thus corroborates our main finding that micro-based and macrobased estimates of the macroeconomic return to health are consistent.

\subsection{Total Years of Schooling}

Table A9 reports the results of an empirical model that proxies education by average years of total schooling instead of average years of secondary schooling. Qualitatively and quantitatively, the results conform closely to our main results. In particular, the estimated macroeconomic return to health is quantitatively almost identical to the main results and lies in the range of plausible microeconomic estimates. At the same time, the estimated macroeconomic return to an additional year of schooling is statistically insignificant in some specifications; however, with values of 5 percent, it still lies at the lower end of the range of plausible values of microeconomic estimates. The variation in this regressor may be less informative than the variation in years of secondary education because primary education and tertiary education vary less over the observation period than years of secondary schooling.

\subsection{Alternative GMM Specifications}

Table A10 presents results for alternative GMM specifications. The rationale for these specification tests is that the empirical results in GMM models may react sensitively to changes in the instrument 
set (see, for example, Roodman, 2009). Specifically, we estimate models that differ from the baseline specification in the following dimensions: a model that eliminates fixed effects using forward-orthogonalized deviations instead of first differences, a model that instruments explanatory variables with second lags rather than first lags, and a model that collapses the instrument set. The corresponding results are qualitatively and quantitatively similar to our main findings and confirm that micro-based and macro-based estimates of the macroeconomic return to health are consistent.

\section{Policy Implications}

The growth literature has used micro-based and macro-based approaches to assess the macroeconomic return to health. Micro-based approaches aggregate the return on health obtained from Mincerian wage regressions to derive the macroeconomic return to health, whereas macrobased approaches estimate generalized production functions decomposing human capital into its components. Macro-based approaches tend to find estimates that are negative and close to zero or 2.5 to 18.5 times larger than micro-based estimates, thereby raising a micro-macro puzzle of the macroeconomic return to health. Our study shows that macro-based estimates of the macroeconomic return to health are compatible with micro-based estimates when we control for the indirect effects of health, which macro-based approaches usually capture but micro-based approaches omit by design. Our estimate indicates that an increase in the adult survival rate of 10 percentage points increases labor productivity by 10.6 percent. This estimate is consistent with the calibrated values of Weil's micro-based approach, which range from 6.7 percent to 13.4 percent when averaging over all microeconomic studies on which his results are based (Weil, 2007). Our results confirm the validity of the micro-based approach and justify its use when estimating the direct economic benefits of health interventions at the macro level.

Our results also indicate that population health can be a source of cross-country differences in income per worker, suggesting that public health measures might be an important lever for fostering economic development. Potential policies along these lines include vaccination programs, antibiotic distribution programs, and micronutrient supplementation schemes, which lead to large improvements in health outcomes for relatively low expenditures (World Bank, 1993; WHO, 2001; Field et al., 2009; Luca et al., 2018). Moreover, policies that target the indirect effects of health on growth—such as birth control, family planning, and educational programs (Bloom et al., 2020; Kotschy et al., 2020)—should complement such policies. 


\section{Acknowledgments}

This version supersedes a previous working paper from 2019 with the same title. The authors would like to thank Ana Abeliansky, Michael Burda, Hendrik Jürges, Alexander Khoury, Michael Kuhn, Wolfgang Lutz, Alexia Prskawetz, Claus Schnabel, Holger Strulik, Uwe Sunde, and many seminar and conference participants for helpful comments and suggestions. David E. Bloom and David Canning wish to acknowledge support from the National Institute on Aging of the National Institutes of Health under Award Number P30AG024409. The content is solely the responsibility of the authors and does not necessarily represent the official views of the National Institutes of Health. Rainer Kotschy wishes to acknowledge financial support by the German Research Foundation through DFG Project 395413683.

\section{References}

Acemoglu, D. and Johnson, S. (2007). Disease and development: The effect of life expectancy on economic growth. Journal of Political Economy 115, 925-985.

Acemoglu, D. and Johnson, S. (2014). Disease and development: A reply to Bloom, Canning, and Fink. Journal of Political Economy 122, 1367-1375.

Aghion, P., Howitt, P., and Murtin, F. (2011). The relationship between health and growth: When Lucas meets Nelson-Phelps. Review of Economics and Institutions 2, 1-24.

Alesina, A., Devleeschauwer, A., Easterly, W., Kurlat, S., and Wacziarg, R. (2003). Fractionalization. Journal of Economic Growth 8, 155-194.

Arellano, M. and Bover, O. (1995). Another look at the instrumental variable estimation of errorcomponents models. Journal of Econometrics 68, 29-51.

Baird, S., Hicks, J. H., Kremer, M., and Miguel, E. (2016). Worms at work: Long-run impacts of a child health investment. Quarterly Journal of Economics 131, 1637-1680.

Barro, R. J. (1997). Determinants of economic growth: A cross-country empirical study. MIT Press, Cambridge, MA.

Barro, R. J. and Lee, J. W. (1994). Sources of economic growth. Carnegie-Rochester Conference Series on Public Policy 40, 1-46.

Barro, R. J. and Lee, J. W. (2013). A new data set of educational attainment in the world, 19502010. Journal of Development Economics 104, 184-198.

Baumol, W. J. (1986). Productivity growth, convergence, and welfare: What the long-run data show. American Economic Review 76, 1072-1085. 
Bils, M. and Klenow, P. J. (2000). Does schooling cause growth? American Economic Review 90, 1160-1183.

Bleakley, H. (2007). Disease and development: Evidence from hookworm eradication in the American South. Quarterly Journal of Economics 122, 73-117.

Bleakley, H. (2010). Health, human capital, and development. Annual Review of Economics 2, 283-310.

Bleakley, H. and Lange, F. (2009). Chronic disease burden and the interaction of education, fertility, and growth. Review of Economics and Statistics 91, 52-65.

Bloom, D. E. and Canning, D. (2002). The health and wealth of nations. Science 287, 1207-1209.

Bloom, D. E., Canning, D., and Fink, G. (2014). Disease and development revisited. Journal of Political Economy 122, 1355-1366.

Bloom, D. E., Canning, D., and Sevilla, J. (2003). The demographic dividend: A new perspective on the economic consequences of population change. Rand Corporation, Santa Monica, CA.

Bloom, D. E., Canning, D., and Sevilla, J. (2004). The effect of health on economic growth: A production function approach. World Development 32, 1-13.

Bloom, D. E., Canning, D., Mansfield, R. K., and Moore, M. (2007). Demographic change, social security systems, and savings. Journal of Monetary Economics 54, 92-114.

Bloom, D. E., Kuhn, M., and Prettner, K. (2018). "Health and economic growth" in Oxford Encyclopedia of Economics and Finance, Hamilton, J. H., Dixit, A., Edwards, S., and Judd, K., Eds. Oxford University Press.

Bloom, D. E., Kuhn, M., and Prettner, K. (2020). The contribution of female health to economic development. Economic Journal 130, 1650-1677.

Bloom, D. E., Kuhn M., and Prettner, K. (2022). Modern infectious diseases: Macroeconomic impacts and policy responses. Journal of Economic Literature 60, 85-131.

Bloom, D. E. and Williamson, J. G. (1998). Demographic transitions and economic miracles in emerging Asia. World Bank Economic Review 12, 419-455.

Blundell, R. and Bond, S. (1998). Initial conditions and moment restrictions in dynamic panel data models. Journal of Econometrics 87, 115-143. 
Caselli, F., Esquivel, G., and Lefort, F. (1996). Reopening the convergence debate: A new look at cross-country growth empirics. Journal of Economic Growth 1, 363-389.

Cass, D. (1965). Optimum growth in an aggregative model of capital accumulation. Review of Economic Studies 32, 233-240.

Cervellati, M. and Sunde, U. (2011). Life expectancy and economic growth: The role of the demographic transition. Journal of Economic Growth 16, 99-133.

Cervellati, M. and Sunde, U. (2013). Life expectancy, schooling, and lifetime labor supply: Theory and evidence revisited. Econometrica 81, 2055-2086.

Cervellati, M. and Sunde, U. (2015). The economic and demographic transition, mortality, and comparative development. American Economic Journal: Macroeconomics 7, 189-225.

Dowrick, S. and Rogers, M. (2002). Classical and technological convergence: Beyond the SolowSwan growth model. Oxford Economic Papers 54, 369-385.

Durlauf, S. N., Johnson, P. A., and Temple, J. R. (2005). "Growth econometrics" in Handbook of Economic Growth, P. Aghion, S. N. Durlauf, Eds. Amsterdam: North Holland, pp. 555-677.

Fagerberg, J. (1994). Technology and international differences in growth rates. Journal of Economic Literature 32, 1147-1175.

Feenstra, R. C., Inklaar, R., and Timmer, M. P. (2015). The next generation of the Penn world table. American Economic Review 105, 3150-3182.

Field, W., Robles, O., and Torero, M. (2009). Iodine deficiency and schooling attainment in Tanzania. American Economic Journal: Applied Economics 1, 140-169.

Gallup, J. L. and Sachs, J. (2001). The economic burden of malaria. American Journal of Tropical Medicine and Hygiene 64, 85-96.

Gallup, J. L., Sachs, J. D., and Mellinger, A. D. (1999). Geography and economic development. International Regional Science Review 22, 179-232.

Galor, O. (2011). Unified growth theory. Princeton University Press, Princeton, NJ.

Galor, O. and Weil, D. N. (2000). Population, technology, and growth: From Malthusian stagnation to the demographic transition and beyond. American Economic Review 90, 806-828.

Gwartney, J., Lawson, R., and Hall, J. (2017). Economic freedom of the world: 2017 annual report Fraser Institute, Vancouver, BC. 
Hall, R. E. and Jones, C. I. (1999). Why do some countries produce so much more output per worker than others? Quarterly Journal of Economics 114, 83-116.

Hansen, C. W. and Lønstrup, L. (2015). The rise in life expectancy and economic growth in the 20th century. Economic Journal 125, 838-852.

Islam, N. (1995). Growth empirics: A panel data approach. Quarterly Journal of Economics 110, 1127-1170.

Kotschy, R. (2021). Health dynamics shape life-cycle incomes. Journal of Health Economics 75, 102398.

Kotschy, R., Suarez Urtaza, P., and Sunde, U. (2020). The demographic dividend is more than an education dividend. Proceedings of the National Academy of Sciences of the United States of America 117, 25982-25984.

Lorentzen, P., McMillan, J., and Wacziarg, R. (2008). Death and development. Journal of Economic Growth 13, 81-124.

Luca, D. L., Iversen, J. H., Lubet, A. S., Mitgang, E., Onarheim, K. H., Prettner, K., and Bloom, D. E. (2018). "Benefits and costs of the women's health targets for the post-2015 development agenda" in Prioritizing Development: A Cost Benefit Analysis of the United Nations' Sustainable Development Goals, B. Lomborg, Ed. Cambridge: Cambridge University Press, pp. 244-254.

Miguel, E. and Kremer, M. (2004). Worms: Identifying impacts on education and health in the presence of treatment externalities. Econometrica 72, 159-217.

Nelson, R. R. and Phelps, E. S. (1966). Investment in humans, technological diffusion, and economic growth. American Economic Review: Papers \& Proceedings 56, 69-75.

Prettner, K. (2013). Population aging and endogenous economic growth. Journal of Population Economics 26, 811-834.

Psacharopoulos, G. and Patrinos, H. A. (2018). Returns to investment in education: A decennial review of the global literature. Education Economics 26, 1-14.

Romer, P. M. (1990). Endogenous technological change. Journal of Political Economy 98, 71-102.

Roodman, D. (2009). A note on the theme of too many instruments. Oxford Bulletin of Economics and Statistics 71, 135-158. 
Sala-i-Martin, X., Doppelhofer, G., and Miller, R. I. (2004). Determinants of long-term growth: A Bayesian averaging of classical estimates (BACE) approach. American Economic Review 94, 813835.

Schultz, T. P. (2002). Wage gains associated with height as a form of health human capital. American Economic Review 92, 349-353.

Shastry, G. K. and Weil, D. N. (2003). How much of cross-country income variation is explained by health? Journal of the European Economic Association 1, 387-396.

Solow, R. M. (1956). A contribution to the theory of economic growth. Quarterly Journal of Economics 70, 65-94.

Solt, F. (2020). Measuring income inequality across countries and over time: The standardized world income inequality database. Social Science Quarterly 103, 1183-1199. SWIID version 9.0.

Strauss, J. and Thomas, D. (1998). Health, nutrition, and economic development. Journal of Economic Literature 36, 766-817.

Strulik, H., Prettner, K., and Prskawetz, A. (2013). The past and future of knowledge-based growth. Journal of Economic Growth 18, 411-437.

Sunde, U. and Vischer, T. (2015). Human capital and growth: Specification matters. Economica 82, 368-390.

UNESCO (1963-1997). Statistical yearbooks. United Nations Educational, Scientific and Cultural Organization, Paris.

UNESCO (2017). Data for sustained development goals. United Nations Educational, Scientific and Cultural Organization, Institute for Statistics, Paris.

United Nations (2017). World population prospects: The 2017 revision. United Nations, Department of Economic and Social Affairs, Population Division, New York.

Weil, D. N. (2007). Accounting for the effect of health on economic growth. Quarterly Journal of Economics 122, 1265-1306.66.

Weil, D. N. (2014). "Health and economic growth" in Handbook of Economic Growth, Aghion, P. and Durlauf, S. N., Eds. North Holland, pp. 623-682.

WHO (2001). Macroeconomics and health: Investing in health for economic development. Commission on Macroeconomics and Health, World Health Organization, Geneva. 
Windmeijer, F. (2005). A finite sample correction for the variance of linear efficient two-step GMM estimators. Journal of Econometrics 126, 25-51.

World Bank (1993). World development report 1993: Investing in health. World Bank, Washington, DC. 


\section{Appendix}

Table A1. Selected Estimates of the Macroeconomic Return to Health in the Literature

\begin{tabular}{lccc}
\hline Study & Health measure & $\begin{array}{c}\text { Coefficient } \\
\text { (standard error) }\end{array}$ & $\begin{array}{c}\text { Growth effect of } \\
\text { increasing adult survival } \\
\text { by 1 percentage point } \\
\text { (of increasing life } \\
\text { expectancy by 1 year) }\end{array}$ \\
\hline Acemoglu and Johnson (2007) & Log life expectancy & $-1.32(0.56)$ & -0.024 \\
Aghion et al. (2011) & Log life expectancy & $1.73(0.74)$ & 0.031 \\
Barro and Lee (1994) & Log life expectancy & $0.073(0.013)$ & 0.130 \\
Bloom et al. (2004) & Life expectancy & $0.040(0.019)$ & 0.048 \\
Bloom and Williamson (1998) & Log life expectancy & $0.040(0.010)$ & 0.071 \\
Caselli et al. (1996) & Log life expectancy & $-0.001(0.032)$ & -0.002 \\
Gallup and Sachs (2001) & Log life expectancy & $0.030(0.009)$ & 0.053 \\
Hansen and Lønstrup (2015) & Log life expectancy & $-1.261(0.358)$ & -0.022 \\
Lorentzen et al. (2008) & Adult mortality rate & $-6.699(3.19)$ & 0.067 \\
Sala-i-Martin et al. (2004) & Life expectancy & $0.081(0.035)$ & 0.098 \\
Shastry and Weil (2003) & Adult survival rate & 0.0018 (n.a.) & 0.018 \\
Weil (2007) & Adult survival rate & 0.653 (n.a.) & 0.007 \\
\hline
\end{tabular}

Note: Author's calculations. The growth effects of a 1-year increase in life expectancy are calculated with a life expectancy of 67.5 years, the average life expectancy in 2000. In the sample, a 1-year increase in life expectancy at birth associates with an 0.83-percentage point increase in the adult survival rate. We adjust all estimates based on life expectancy by the inverse of this relation, so that the growth effects are comparable across the different measures of population health. Shastry and Weil's (2003) and Weil's (2007) coefficients base upon micro calibrations, so that no standard errors are available.

Table A1 presents the estimated effects of health on economic growth from several prominent studies. To compare the estimates, we calculate the implied change in the growth rate either for a 1-percentage-point change in the adult survival rate or for a 1-year change in life expectancy at birth. Many studies estimate the elasticity of growth with respect to a 1-percent increase in life expectancy rather than a 1-year increase. For these studies, we calculate the growth effects with a life expectancy of 67.5 years, the average life expectancy in 2000 . Using this value creates conservative growth effects because the literature's results base upon data from 2000 or before. In our sample, a 1-year increase in life expectancy at birth associates with an 0.83-percentage point increase in the adult survival rate. We adjust all estimates based on life expectancy by the inverse of this relation, so that the growth effects are comparable across the different measures of population health. Further multiplying the estimates by 10 gives the growth effect of increasing the adult survival rate by 10 percentage points, which we use to derive our main results in Table 3 .

Most of the listed papers suggest a positive effect of population health on growth. Among them, the macro-based approaches find sizable macroeconomic returns to health: a 1-year increase in life expectancy associates with an increase in income per worker between 3.1 and 13 percent. These estimates are 4.5 to 18.5 times larger than Weil's (2007) micro-based benchmark estimate of 0.7 percent, and they significantly differ from Weil's estimate at conventional significance levels. Even when accounting for the uncertainty of Weil's estimate, the macro-based estimates remain 2.5- 
18.5 times larger than the corresponding micro-based calibration of 0.13 percent. A few listed papers find a small negative effect of population health on growth. The results of these studies again differ significantly from Weil's micro-based estimate and the microeconomic literature in general. The only exception is Caselli et al.'s (1996) estimate, which-due to its large standard error-is consistent with almost all positive and negative estimates in the literature. Altogether, the macro-based evidence seems to conflict with the micro-based evidence, thus presenting a micromacro puzzle of the economic return on health. See Weil (2014) and Bloom et al. (2018) for more detailed surveys of the literature on the relation between health and growth. 
Table A2. Descriptive Statistics

\begin{tabular}{|c|c|c|c|c|c|}
\hline Variables (units) & Obs. & Mean & Std. Dev. & Min & $\operatorname{Max}$ \\
\hline \multicolumn{6}{|l|}{ Income (GDP) and physical capital } \\
\hline Log income per capita (in log points, income in USD) & 1020 & 9.03 & 1.19 & 6.32 & 12.40 \\
\hline Growth of income per capita (in log points) & 1020 & 0.12 & 0.21 & -1.22 & 1.23 \\
\hline Log income per worker (in log points, income in USD) & 1020 & 9.99 & 1.10 & 7.27 & 13.01 \\
\hline Growth of income per worker (in log points) & 1020 & 0.10 & 0.21 & -1.24 & 1.27 \\
\hline Log capital per worker (in log points, income in USD) & 1020 & 11.46 & 1.41 & 6.80 & 14.55 \\
\hline Growth of capital per worker (in log points) & 1020 & 0.09 & 0.15 & -0.48 & 1.04 \\
\hline \multicolumn{6}{|l|}{ Health and schooling } \\
\hline Adult survival rate & 1020 & 0.80 & 0.11 & 0.28 & 0.95 \\
\hline Change in adult survival rate & 1020 & 0.01 & 0.03 & -0.27 & 0.21 \\
\hline Life expectancy at birth (in years) & 1020 & 67.02 & 10.10 & 23.72 & 83.28 \\
\hline Change in life expectancy at birth (in years) & 1020 & 1.49 & 1.90 & -24.35 & 21.02 \\
\hline Secondary schooling (in years) & 1020 & 2.58 & 1.54 & 0.06 & 7.91 \\
\hline Change of secondary schooling (in years) & 1020 & 0.26 & 0.26 & -1.07 & 1.64 \\
\hline Total schooling (in years) & 1020 & 7.49 & 3.07 & 0.46 & 13.27 \\
\hline Change in total schooling (in years) & 1020 & 0.52 & 0.39 & -1.13 & 2.62 \\
\hline \multicolumn{6}{|l|}{ Additional controls } \\
\hline Institutional quality (on scale $0-10$ ) & 1020 & 6.08 & 1.31 & 1.82 & 9.05 \\
\hline Log support ratio (in $\log$ points) & 1020 & -0.50 & 0.12 & -0.76 & -0.15 \\
\hline Growth of working-age pop./total pop. (in log points) & 1020 & 0.01 & 0.02 & -0.05 & 0.13 \\
\hline Experience (in years) & 974 & 12.45 & 7.37 & 0.50 & 31.30 \\
\hline Change in experience (in years) & 948 & 0.63 & 1.56 & -11.40 & 5.70 \\
\hline Income inequality (in Gini points) & 810 & 0.46 & 0.07 & 0.22 & 0.72 \\
\hline Change in income inequality (in Gini points) & 731 & 0.00 & 0.01 & -0.05 & 0.11 \\
\hline Population growth (in log points) & 1020 & 0.08 & 0.07 & -0.27 & 0.72 \\
\hline Trade openness (ratio of imports and exports to GDP) & 1020 & 0.53 & 0.49 & 0.02 & 6.21 \\
\hline Land area in tropics (in percent, $0-1$ ) & 969 & 0.45 & 0.47 & 0.00 & 1.00 \\
\hline Land area within $100 \mathrm{~km}$ of coast (in percent, $0-1$ ) & 969 & 0.38 & 0.36 & 0.00 & 1.00 \\
\hline Ethnic fractionalization (in percent, $0-1$ ) & 1001 & 0.42 & 0.26 & 0.00 & 0.93 \\
\hline
\end{tabular}

Note: Descriptive statistics for 133 countries observed every five years from 1965 to 2015 . GDP stands for gross domestic product. 
Table A3. Countries Included in the Sample

\begin{tabular}{|c|c|c|c|c|}
\hline Country & $\begin{array}{c}\text { Full } \\
\text { sample }\end{array}$ & $\begin{array}{c}\text { Balanced } \\
\text { sample }\end{array}$ & $\begin{array}{c}\text { No advanced } \\
\text { economies }\end{array}$ & $\begin{array}{c}\text { No socialist } \\
\text { countries }\end{array}$ \\
\hline Albania & $\checkmark$ & $x$ & $\checkmark$ & $x$ \\
\hline Algeria & $\checkmark$ & $x$ & 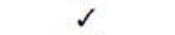 & $s$ \\
\hline Argentina & $\checkmark$ & $\checkmark$ & $\checkmark$ & $\checkmark$ \\
\hline Armenia & $\checkmark$ & $x$ & $\checkmark$ & $x$ \\
\hline Australia & $\checkmark$ & $\checkmark$ & $x$ & $\checkmark$ \\
\hline Austria & $\checkmark$ & $\checkmark$ & $x$ & $\checkmark$ \\
\hline Bahrain & 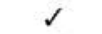 & $x$ & $\checkmark$ & 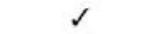 \\
\hline Bangladesh & $\checkmark$ & $x$ & $a$ & $d$ \\
\hline Barbados & $\checkmark$ & $x$ & $\checkmark$ & $\checkmark$ \\
\hline Belgium & $\checkmark$ & $\checkmark$ & $x$ & $\checkmark$ \\
\hline Belize & $\checkmark$ & $x$ & $s$ & $s$ \\
\hline Benin & $\checkmark$ & $x$ & $\checkmark$ & $x$ \\
\hline Bolivia & $\checkmark$ & $x$ & 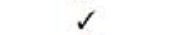 & 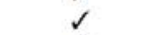 \\
\hline Botswana & $\checkmark$ & $x$ & $\checkmark$ & $\checkmark$ \\
\hline Brazil & $\checkmark$ & $\checkmark$ & $\checkmark$ & $\checkmark$ \\
\hline Brunei & $\checkmark$ & $x$ & $\checkmark$ & $\checkmark$ \\
\hline Bulgaria & $\checkmark$ & $x$ & $\checkmark$ & $x$ \\
\hline Burundi & $\checkmark$ & $x$ & $d$ & 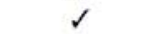 \\
\hline Cambodia & $\checkmark$ & $x$ & $\checkmark$ & $x$ \\
\hline Cameroon & $\checkmark$ & $x$ & $\checkmark$ & $\checkmark$ \\
\hline Canada & $\checkmark$ & $\checkmark$ & $x$ & $\checkmark$ \\
\hline Central African Republic & $\checkmark$ & $x$ & $\checkmark$ & $\checkmark$ \\
\hline Chile & $\checkmark$ & $\checkmark$ & $x$ & $\checkmark$ \\
\hline China & $\checkmark$ & $x$ & $\checkmark$ & $x$ \\
\hline Colombia & $\checkmark$ & $\checkmark$ & $\checkmark$ & $\checkmark$ \\
\hline Congo & $\checkmark$ & $x$ & $\checkmark$ & $x$ \\
\hline Congo DR & $\checkmark$ & $\checkmark$ & $\checkmark$ & $x$ \\
\hline Costa Rica & $\checkmark$ & $x$ & $\checkmark$ & 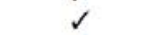 \\
\hline Croatia & $\checkmark$ & $x$ & $\checkmark$ & $x$ \\
\hline Cyprus & $\checkmark$ & $x$ & $\checkmark$ & $\checkmark$ \\
\hline Czechia & 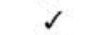 & $x$ & $x$ & $x$ \\
\hline Denmark & $\checkmark$ & $\checkmark$ & $x$ & $\checkmark$ \\
\hline Dominican Republic & $\checkmark$ & $x$ & $\checkmark$ & $\checkmark$ \\
\hline Ecuador & $\checkmark$ & $\checkmark$ & $\checkmark$ & $\checkmark$ \\
\hline Egypt & $\checkmark$ & $x$ & $\checkmark$ & $\checkmark$ \\
\hline EI Salvador & $\checkmark$ & $x$ & 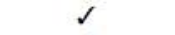 & $\checkmark$ \\
\hline Estonia & $\checkmark$ & $x$ & $x$ & $x$ \\
\hline Eswatini & $\checkmark$ & $x$ & $\checkmark$ & $\checkmark$ \\
\hline Fiji & $\checkmark$ & $x$ & $\checkmark$ & 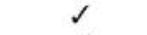 \\
\hline Finland & $\checkmark$ & $\checkmark$ & $x$ & $\checkmark$ \\
\hline France & $\checkmark$ & $\checkmark$ & $x$ & $\checkmark$ \\
\hline Gabon & $\checkmark$ & $x$ & $\checkmark$ & $\checkmark$ \\
\hline Gambia & $\checkmark$ & $x$ & 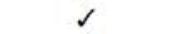 & $\checkmark$ \\
\hline Germany & $\checkmark$ & $\checkmark$ & $x$ & $\checkmark$ \\
\hline Ghana & $\checkmark$ & $x$ & $\checkmark$ & $\checkmark$ \\
\hline Greece & 2 & 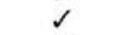 & $x$ & 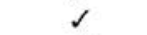 \\
\hline Guatemala & $\checkmark$ & $\checkmark$ & $\checkmark$ & $\checkmark$ \\
\hline Haiti & $\checkmark$ & $x$ & 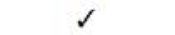 & $a$ \\
\hline Honduras & $\checkmark$ & $x$ & $\checkmark$ & $\checkmark$ \\
\hline Hungary & $\checkmark$ & $x$ & $x$ & $x$ \\
\hline Iceland & 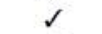 & $\checkmark$ & $x$ & 1 \\
\hline India & $\checkmark$ & $\checkmark$ & $\checkmark$ & $\checkmark$ \\
\hline Indonesia & $\checkmark$ & $\checkmark$ & $\checkmark$ & $\checkmark$ \\
\hline Iran & $\checkmark$ & $\checkmark$ & $\checkmark$ & $\checkmark$ \\
\hline Ireland & $\checkmark$ & $\checkmark$ & $x$ & $\checkmark$ \\
\hline Israel & $\checkmark$ & $\checkmark$ & $x$ & $\checkmark$ \\
\hline Italy & $\checkmark$ & $\checkmark$ & $x$ & $\checkmark$ \\
\hline Ivory Coast & $\checkmark$ & $x$ & $\checkmark$ & $\checkmark$ \\
\hline Jamaica & $\checkmark$ & $x$ & $\checkmark$ & $\checkmark$ \\
\hline Japan & $\checkmark$ & $\checkmark$ & $x$ & $\checkmark$ \\
\hline Jordan & $\checkmark$ & $x$ & $\checkmark$ & $\checkmark$ \\
\hline Kazakhstan & $\checkmark$ & $x$ & $\checkmark$ & $x$ \\
\hline Kenya & $\checkmark$ & $\checkmark$ & $\checkmark$ & 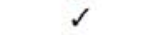 \\
\hline Kuwait & $\checkmark$ & $x$ & $\checkmark$ & $\checkmark$ \\
\hline Kyrgyzstan & $\checkmark$ & $x$ & $\checkmark$ & $x$ \\
\hline Laos & $\checkmark$ & $x$ & $\checkmark$ & $x$ \\
\hline Latvia & $\checkmark$ & $x$ & $x$ & $x$ \\
\hline
\end{tabular}


Table A3. Countries Included in the Sample (Continued)

\begin{tabular}{|c|c|c|c|c|}
\hline Country & $\begin{array}{c}\text { Full } \\
\text { sample }\end{array}$ & $\begin{array}{l}\text { Balanced } \\
\text { sample }\end{array}$ & $\begin{array}{l}\text { No advanced } \\
\text { economies }\end{array}$ & $\begin{array}{l}\text { No socialist } \\
\text { countries }\end{array}$ \\
\hline Lesotho & $\checkmark$ & $x$ & $\checkmark$ & $\checkmark$ \\
\hline Liberia & $\checkmark$ & $x$ & $\checkmark$ & $\checkmark$ \\
\hline Lithuania & $\checkmark$ & $x$ & $\checkmark$ & $x$ \\
\hline Luxembourg & $\checkmark$ & $\checkmark$ & $x$ & $\checkmark$ \\
\hline Malawi & $\checkmark$ & $x$ & $\checkmark$ & $\checkmark$ \\
\hline Malaysia & $\checkmark$ & $\checkmark$ & $\checkmark$ & $\checkmark$ \\
\hline Mali & $\checkmark$ & $x$ & $\checkmark$ & $\checkmark$ \\
\hline Malta & 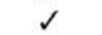 & $x$ & 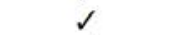 & 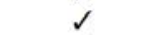 \\
\hline Mauritania & $\checkmark$ & $x$ & $\checkmark$ & $\checkmark$ \\
\hline Mauritius & $\checkmark$ & $x$ & $\checkmark$ & $\checkmark$ \\
\hline Mexico & $\checkmark$ & $\checkmark$ & $x$ & $\checkmark$ \\
\hline Moldova & $\checkmark$ & $x$ & $\checkmark$ & $x$ \\
\hline Mongolia & $\checkmark$ & $x$ & $\checkmark$ & $x$ \\
\hline Morocco & $\checkmark$ & $\checkmark$ & $\checkmark$ & $s$ \\
\hline Mozambique & $\checkmark$ & $x$ & $\checkmark$ & $x$ \\
\hline Myanmar & 2 & $x$ & 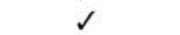 & 1 \\
\hline Namibia & $\checkmark$ & $x$ & $\checkmark$ & $\checkmark$ \\
\hline Nepal & $\checkmark$ & $x$ & $\checkmark$ & $\checkmark$ \\
\hline Netherlands & $\checkmark$ & $\checkmark$ & $x$ & $\checkmark$ \\
\hline New Zealand & $\checkmark$ & $\checkmark$ & $x$ & $\checkmark$ \\
\hline Nicaragua & $\checkmark$ & $x$ & $\checkmark$ & $\checkmark$ \\
\hline Niger & $\checkmark$ & $x$ & $\checkmark$ & $\checkmark$ \\
\hline Norway & $\checkmark$ & $\checkmark$ & $x$ & 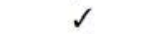 \\
\hline Pakistan & 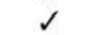 & 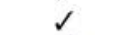 & 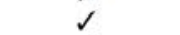 & 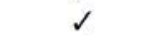 \\
\hline Panama & $\checkmark$ & $x$ & $\checkmark$ & $\checkmark$ \\
\hline Paraguay & $\checkmark$ & $x$ & $\checkmark$ & 2 \\
\hline Peru & $\checkmark$ & $\checkmark$ & $\checkmark$ & $\checkmark$ \\
\hline Philippines & $\checkmark$ & $\checkmark$ & $\checkmark$ & $\checkmark$ \\
\hline Poland & $\checkmark$ & $x$ & $x$ & $x$ \\
\hline Portugal & $\checkmark$ & $\checkmark$ & $x$ & $\checkmark$ \\
\hline Qatar & $\checkmark$ & $x$ & $\checkmark$ & $\checkmark$ \\
\hline Romania & $\checkmark$ & $x$ & $\checkmark$ & $x$ \\
\hline Russia & $\checkmark$ & $x$ & $\checkmark$ & $x$ \\
\hline Rwanda & $\checkmark$ & $x$ & $\checkmark$ & $\checkmark$ \\
\hline Saudi Arabia & $\checkmark$ & $x$ & $\checkmark$ & $\checkmark$ \\
\hline Senegal & $\checkmark$ & $x$ & $\checkmark$ & $\checkmark$ \\
\hline Serbia & $\checkmark$ & $x$ & $\checkmark$ & $x$ \\
\hline Sierra Leone & $\checkmark$ & $x$ & $\checkmark$ & $\checkmark$ \\
\hline Singapore & $\checkmark$ & $\checkmark$ & $\checkmark$ & $\checkmark$ \\
\hline Slovakia & $\checkmark$ & $x$ & $x$ & $x$ \\
\hline Slovenia & $\checkmark$ & $x$ & $x$ & $x$ \\
\hline South Africa & $\checkmark$ & $\checkmark$ & $\checkmark$ & $\checkmark$ \\
\hline South Korea & $\checkmark$ & $\checkmark$ & $x$ & $\checkmark$ \\
\hline Spain & $\checkmark$ & $\checkmark$ & $x$ & $\checkmark$ \\
\hline Sri Lanka & $\checkmark$ & $x$ & $\checkmark$ & $\checkmark$ \\
\hline Sweden & $\checkmark$ & $\checkmark$ & $x$ & $\checkmark$ \\
\hline Switzerland & $\checkmark$ & $\checkmark$ & $x$ & $\checkmark$ \\
\hline Syria & $\checkmark$ & $\checkmark$ & $\checkmark$ & $\checkmark$ \\
\hline Tajikistan & $\checkmark$ & $x$ & $\checkmark$ & $x$ \\
\hline Tanzania & $\checkmark$ & $\checkmark$ & $\checkmark$ & $\checkmark$ \\
\hline Thailand & $\checkmark$ & $\checkmark$ & $\checkmark$ & $\checkmark$ \\
\hline Togo & $\checkmark$ & $x$ & $\checkmark$ & $\checkmark$ \\
\hline Trinidad and Tobago & $\checkmark$ & $x$ & $\checkmark$ & $\checkmark$ \\
\hline Tunisia & $\checkmark$ & $\checkmark$ & $\checkmark$ & $\checkmark$ \\
\hline Turkey & $\checkmark$ & $\checkmark$ & $x$ & $\checkmark$ \\
\hline Uganda & $\checkmark$ & $x$ & 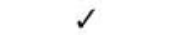 & 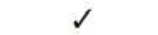 \\
\hline Ukraine & $\checkmark$ & $x$ & $\checkmark$ & $x$ \\
\hline United Arab Emirates & $\checkmark$ & $x$ & $\checkmark$ & $\checkmark$ \\
\hline United Kingdom & $\checkmark$ & $\checkmark$ & $x$ & $\checkmark$ \\
\hline United States of America & $\checkmark$ & $\checkmark$ & $x$ & $\checkmark$ \\
\hline Uruguay & $\checkmark$ & $x$ & $\checkmark$ & $\checkmark$ \\
\hline Venezuela & $\checkmark$ & $\checkmark$ & $\checkmark$ & $x$ \\
\hline Vietnam & $\checkmark$ & $x$ & $\checkmark$ & $x$ \\
\hline Yemen & $\checkmark$ & $x$ & $\checkmark$ & $\checkmark$ \\
\hline Zambia & $\checkmark$ & $x$ & $\checkmark$ & $\checkmark$ \\
\hline Zimbabwe & $\checkmark$ & $x$ & $\checkmark$ & $\checkmark$ \\
\hline
\end{tabular}


Table A4. The Macroeconomic Return to Health Across Models: Full Results

\begin{tabular}{|c|c|c|c|c|c|c|}
\hline \multirow[t]{2}{*}{ Dependent variable } & \multicolumn{6}{|c|}{ Growth rate of income per capita } \\
\hline & $\begin{array}{c}\text { Baseline } \\
\text { controls } \\
\text { (1) }\end{array}$ & $\begin{array}{c}\text { Including } \\
\text { working } \\
\text { experience } \\
(2)\end{array}$ & $\begin{array}{c}\text { Including } \\
\text { income } \\
\text { inequality } \\
(3)\end{array}$ & $\begin{array}{c}\text { Including } \\
\text { lagged } \\
\text { controls } \\
(4)\end{array}$ & $\begin{array}{l}\text { Country } \\
\text { growth } \\
\text { trends } \\
(5)\end{array}$ & $\begin{array}{c}\text { Panel } \\
\text { GMM } \\
\\
(6)\end{array}$ \\
\hline Log income per capita $(t-1)$ & $\begin{array}{c}-0.070^{* * *} \\
(0.009)\end{array}$ & $\begin{array}{c}-0.071^{* * * *} \\
(0.009)\end{array}$ & $\begin{array}{c}-0.073^{* * *} \\
(0.011)\end{array}$ & $\begin{array}{c}-0.158^{* * *} \\
(0.014)\end{array}$ & $\begin{array}{c}-0.270^{* * *} \\
(0.034)\end{array}$ & $\begin{array}{c}-0.060^{* * *} \\
(0.023)\end{array}$ \\
\hline Growth of capital per worker & $\begin{array}{c}0.344^{* * * *} \\
(0.049)\end{array}$ & $\begin{array}{c}0.355^{* * *} \\
(0.048)\end{array}$ & $\begin{array}{c}0.284^{* * *} \\
(0.058)\end{array}$ & $\begin{array}{c}0.343^{* * *} \\
(0.059)\end{array}$ & $\begin{array}{c}0.257^{* * *} \\
(0.082)\end{array}$ & $\begin{array}{c}0.364^{* * *} \\
(0.051)\end{array}$ \\
\hline Change in adult survival & $\begin{array}{c}0.698^{* * *} \\
(0.258)\end{array}$ & $\begin{array}{c}0.899 * * * \\
(0.238)\end{array}$ & $\begin{array}{c}0.792^{* * *} \\
(0.301)\end{array}$ & $\begin{array}{c}0.694^{* * *} \\
(0.253)\end{array}$ & $\begin{array}{l}0.394^{*} \\
(0.220)\end{array}$ & $\begin{array}{c}0.653^{* *} \\
(0.271)\end{array}$ \\
\hline Change in secondary schooling & $\begin{array}{c}0.068^{* * *} \\
(0.024)\end{array}$ & $\begin{array}{c}0.065^{* * *} \\
(0.024)\end{array}$ & $\begin{array}{c}0.057^{* *} \\
(0.023)\end{array}$ & $\begin{array}{c}0.030 \\
(0.023)\end{array}$ & $\begin{array}{l}0.049^{*} \\
(0.026)\end{array}$ & $\begin{array}{r}0.062^{* *} \\
(0.028)\end{array}$ \\
\hline $\begin{array}{l}\text { Growth of working-age population/ } \\
\text { total population }\end{array}$ & $\begin{array}{c}1.043^{* * *} \\
(0.306)\end{array}$ & $\begin{array}{c}1.051^{* * *} \\
(0.345)\end{array}$ & $\begin{array}{c}0.989^{* *} \\
(0.405)\end{array}$ & $\begin{array}{c}0.983^{* * *} \\
(0.291)\end{array}$ & $\begin{array}{c}0.231 \\
(0.415)\end{array}$ & $\begin{array}{c}0.968^{* * *} \\
(0.361)\end{array}$ \\
\hline Secondary schooling $(t-1)$ & $\begin{array}{c}0.034^{* * *} \\
(0.007)\end{array}$ & $\begin{array}{c}0.033 * * * \\
(0.007)\end{array}$ & $\begin{array}{c}0.031 * * * \\
(0.008)\end{array}$ & $\begin{array}{l}0.015^{* *} \\
(0.008)\end{array}$ & $\begin{array}{l}0.038^{* *} \\
(0.017)\end{array}$ & $\begin{array}{c}0.037^{* *} \\
(0.017)\end{array}$ \\
\hline Institutional quality & $\begin{array}{c}0.061^{* * *} \\
(0.009)\end{array}$ & $\begin{array}{c}0.060^{* * *} \\
(0.009)\end{array}$ & $\begin{array}{c}0.068^{* * *} \\
(0.012)\end{array}$ & $\begin{array}{c}0.057^{* * *} \\
(0.009)\end{array}$ & $\begin{array}{c}0.083^{* * *} \\
(0.013)\end{array}$ & $\begin{array}{c}0.064^{* * * *} \\
(0.012)\end{array}$ \\
\hline Change in experience & - & $\begin{array}{c}-0.005 \\
(0.008)\end{array}$ & - & - & - & - \\
\hline Change in experience squared & - & $\begin{array}{l}0.000 \\
(0.000)\end{array}$ & - & $\begin{array}{l}- \\
-\end{array}$ & - & - \\
\hline Change in income inequality & - & - & $\begin{array}{l}-0.645^{*} \\
(0.377)\end{array}$ & - & - & - \\
\hline Capital per worker $(t-1)$ & - & - & - & $\begin{array}{c}0.059^{* * *} \\
(0.010)\end{array}$ & - & - \\
\hline Adult survival $(t-1)$ & - & - & - & $\begin{array}{c}0.146^{* *} \\
(0.070)\end{array}$ & - & - \\
\hline $\begin{array}{l}\text { Working-age population/ } \\
\text { total population }\end{array}$ & - & - & - & $\begin{array}{c}0.441^{* * *} \\
(0.113)\end{array}$ & - & - \\
\hline Countries & 133 & 131 & 131 & 133 & 133 & 133 \\
\hline Observations & 1020 & 948 & 731 & 1020 & 1020 & 1020 \\
\hline$R^{2}$ & 0.29 & 0.30 & - & 0.34 & 0.33 & - \\
\hline $\operatorname{AR}(2) p$-value & - & - & - & - & - & 0.10 \\
\hline Hansen $p$-value & - & - & - & - & - & 0.15 \\
\hline Diff.-in-Hansen $p$-value & - & - & - & - & - & 0.97 \\
\hline
\end{tabular}

Note: Estimation results for five-year panels of 133 countries over the period 1965-2015. Estimates are derived from ordinary least squares in specifications (1) to (5) and system GMM in (6). All specifications include time fixed effects, controls for lagged years of secondary schooling, and quality of economic institutions. Specification (2) includes controls for experience and experience squared; specification (3) includes the pre-tax, pre-transfer Gini coefficient; and specification (4) includes lagged controls for physical capital per worker, population health, and the size of the working-age population relative to the total population. Specifications in (5) and (6) account for country-specific growth trends by including country fixed effects. The panel GMM specification in (6) uses the first lag of the endogenous variables in the difference equation and the first difference of the endogenous variables in the level equation as instruments; standard errors in this specification are computed with the two-step procedure and corrected with respect to finite sample size (Windmeijer, 2005). Standard errors are clustered on the country level and reported in parentheses. Asterisks indicate significance levels: ${ }^{\star} p<0.1$; ${ }^{\star \star} p<0.05 ;{ }^{* \star \star} p<0.01$. 
Table A5. The Macroeconomic Return to Health Across Models

\begin{tabular}{|c|c|c|c|c|c|c|}
\hline & $\begin{array}{l}\text { Baseline } \\
\text { controls } \\
\text { (1) }\end{array}$ & $\begin{array}{c}\text { Including } \\
\text { working } \\
\text { experience } \\
\text { (2) }\end{array}$ & $\begin{array}{c}\text { Including } \\
\text { income } \\
\text { inequality } \\
\text { (3) }\end{array}$ & $\begin{array}{l}\text { Including } \\
\text { lagged } \\
\text { controls } \\
(4)\end{array}$ & $\begin{array}{l}\text { Country } \\
\text { growth } \\
\text { trends } \\
\quad(5)\end{array}$ & $\begin{array}{c}\text { Panel } \\
\text { GMM } \\
(6)\end{array}$ \\
\hline$\phi_{h}$ & $10.6 \%$ & $13.9 \%$ & $11.1 \%$ & $10.6 \%$ & $5.3 \%$ & $10.3 \%$ \\
\hline
\end{tabular}

Note: This table reports the return on health $\phi_{h}$ across all specifications of Table 1 in the main text. Estimates are obtained by dividing the regression coefficients of the change in adult survival by $(1-\alpha)$, where $\alpha$ is estimated growth of capital per worker. All estimates are multiplied by 10 to match a 10-percentage-point increase in adult survival. 
Table A6. Robustness: Additional Controls

\begin{tabular}{|c|c|c|c|c|c|c|}
\hline \multirow[t]{2}{*}{ Dependent variable } & \multicolumn{6}{|c|}{ Growth rate of income per capita } \\
\hline & (1) & $(2)$ & (3) & (4) & (5) & (6) \\
\hline Log income per capita $(t-1)$ & $\begin{array}{c}-0.070^{* * *} \\
(0.009)\end{array}$ & $\begin{array}{c}-0.069^{* * *} \\
(0.009)\end{array}$ & $\begin{array}{c}-0.072^{* * *} \\
(0.009)\end{array}$ & $\begin{array}{c}-0.078^{* * *} \\
(0.010)\end{array}$ & $\begin{array}{c}-0.069 * * * \\
(0.010)\end{array}$ & $\begin{array}{c}-0.071^{* * *} \\
(0.009)\end{array}$ \\
\hline Growth of capital per worker & $\begin{array}{c}0.344^{* * *} \\
(0.049)\end{array}$ & $\begin{array}{c}0.310^{* * *} \\
(0.048)\end{array}$ & $\begin{array}{c}0.344^{* * *} \\
(0.049)\end{array}$ & $\begin{array}{c}0.325 * * * \\
(0.051)\end{array}$ & $\begin{array}{c}0.362^{* * *} \\
(0.049)\end{array}$ & $\begin{array}{c}0.325^{* * *} \\
(0.050)\end{array}$ \\
\hline Change in adult survival & $\begin{array}{c}0.698^{* * *} \\
(0.258)\end{array}$ & $\begin{array}{c}0.763^{* * *} \\
(0.273)\end{array}$ & $\begin{array}{c}0.702^{* * *} \\
(0.258)\end{array}$ & $\begin{array}{c}0.630^{* *} \\
(0.256)\end{array}$ & $\begin{array}{c}0.685^{* * *} \\
(0.260)\end{array}$ & $\begin{array}{l}0.559^{*} \\
(0.297)\end{array}$ \\
\hline Change in secondary schooling & $\begin{array}{c}0.068 * * * \\
(0.024)\end{array}$ & $\begin{array}{l}0.061^{* *} \\
(0.025)\end{array}$ & $\begin{array}{c}0.067^{* * *} \\
(0.024)\end{array}$ & $\begin{array}{c}0.066^{* * *} \\
(0.025)\end{array}$ & $\begin{array}{c}0.069 * * * \\
(0.025)\end{array}$ & $\begin{array}{c}0.059 * * \\
(0.023)\end{array}$ \\
\hline $\begin{array}{l}\text { Growth of working-age population/ } \\
\text { total population }\end{array}$ & $\begin{array}{c}1.043^{* * *} \\
(0.306)\end{array}$ & $\begin{array}{c}1.117^{* * *} \\
(0.316)\end{array}$ & $\begin{array}{c}1.056^{* * *} \\
(0.307)\end{array}$ & $\begin{array}{c}1.035^{* * *} \\
(0.322)\end{array}$ & $\begin{array}{c}1.001^{* * *} \\
(0.332)\end{array}$ & $\begin{array}{c}1.066^{* * *} \\
(0.315)\end{array}$ \\
\hline Population growth & - & $\begin{array}{l}-0.267^{*} \\
(0.139)\end{array}$ & - & - & - & - \\
\hline Trade openness & - & - & $\begin{array}{c}0.018 \\
(0.012)\end{array}$ & - & - & - \\
\hline Tropical land area & - & - & - & $\begin{array}{c}-0.057^{* * *} \\
(0.017)\end{array}$ & - & - \\
\hline Land area within $100 \mathrm{~km}$ of coast & - & - & - & - & $\begin{array}{l}-0.005 \\
(0.020)\end{array}$ & - \\
\hline Ethnic fractionalization & - & - & - & - & - & $\begin{array}{c}-0.068^{* *} \\
(0.030)\end{array}$ \\
\hline Countries & 133 & 133 & 133 & 127 & 127 & 130 \\
\hline Observations & 1020 & 1020 & 1020 & 969 & 969 & 1001 \\
\hline$R^{2}$ & 0.29 & 0.29 & 0.29 & 0.30 & 0.29 & 0.29 \\
\hline
\end{tabular}

Note: Estimation results for five-year panels of up to 133 countries over the period 1965--2015. Estimates are derived from ordinary least squares. All specifications include time fixed effects, controls for lagged years of secondary schooling, and quality of economic institutions. Standard errors are clustered on the country level and reported in parentheses Asterisks indicate significance levels: * $p<0.1 ;{ }^{* *} p<0.05$; ${ }^{* \star}$ $\mathrm{p}<0.01$. 
Table A7. Robustness: Income per Worker

\begin{tabular}{|c|c|c|c|c|c|c|}
\hline \multirow[t]{2}{*}{ Dependent variable } & \multicolumn{6}{|c|}{ Growth rate of income per worker } \\
\hline & $\begin{array}{c}\text { Baseline } \\
\text { controls } \\
\text { (1) }\end{array}$ & $\begin{array}{c}\text { Including } \\
\text { working } \\
\text { experience } \\
\quad(2)\end{array}$ & $\begin{array}{c}\text { Including } \\
\text { income } \\
\text { inequality } \\
(3)\end{array}$ & $\begin{array}{c}\text { Including } \\
\text { lagged } \\
\text { controls } \\
(4)\end{array}$ & $\begin{array}{l}\text { Country } \\
\text { growth } \\
\text { trends } \\
\quad(5)\end{array}$ & $\begin{array}{c}\text { Panel } \\
\text { GMM } \\
\text { (6) }\end{array}$ \\
\hline Log income per worker $(t-1)$ & $\begin{array}{c}-0.068^{* * *} \\
(0.009)\end{array}$ & $\begin{array}{c}-0.071^{* * *} \\
(0.010)\end{array}$ & $\begin{array}{c}-0.071^{* * *} \\
(0.012)\end{array}$ & $\begin{array}{c}-0.154^{* * *} \\
(0.014)\end{array}$ & $\begin{array}{c}-0.278^{* * *} \\
(0.032)\end{array}$ & $\begin{array}{c}-0.073^{* * *} \\
(0.023)\end{array}$ \\
\hline Growth of capital per worker & $\begin{array}{c}0.459^{* * *} \\
(0.045)\end{array}$ & $\begin{array}{c}0.469^{* * *} \\
(0.045)\end{array}$ & $\begin{array}{c}0.410^{* * *} \\
(0.054)\end{array}$ & $\begin{array}{c}0.544^{* * *} \\
(0.052)\end{array}$ & $\begin{array}{c}0.411^{* * *} \\
(0.074)\end{array}$ & $\begin{array}{c}0.465^{* * *} \\
(0.046)\end{array}$ \\
\hline Change in adult survival & $\begin{array}{c}0.589 * * \\
(0.282)\end{array}$ & $\begin{array}{c}0.794^{* * *} \\
(0.262)\end{array}$ & $\begin{array}{c}0.685^{* *} \\
(0.328)\end{array}$ & $\begin{array}{c}0.613^{* *} \\
(0.285)\end{array}$ & $\begin{array}{c}0.364 \\
(0.258)\end{array}$ & $\begin{array}{l}0.601^{* *} \\
(0.302)\end{array}$ \\
\hline Change in secondary schooling & $\begin{array}{c}0.064^{* * *} \\
(0.024)\end{array}$ & $\begin{array}{c}0.061^{* *} \\
(0.025)\end{array}$ & $\begin{array}{c}0.057^{* *} \\
(0.023)\end{array}$ & $\begin{array}{c}0.037 \\
(0.023)\end{array}$ & $\begin{array}{c}0.038 \\
(0.026)\end{array}$ & $\begin{array}{c}0.058^{* *} \\
(0.027)\end{array}$ \\
\hline Countries & 133 & 131 & 131 & 133 & 133 & 133 \\
\hline Observations & 1020 & 948 & 731 & 1020 & 1020 & 1020 \\
\hline$R^{2}$ & 0.30 & 0.31 & - & 0.35 & 0.35 & - \\
\hline $\mathrm{AR}(2) p$-value & - & - & - & - & - & 0.04 \\
\hline Hansen $p$-value & - & - & - & - & - & 0.13 \\
\hline Diff.-in-Hansen $p$-value & - & - & - & - & - & 0.96 \\
\hline
\end{tabular}

Note: Estimation results for five-year panels of 133 countries over the period 1965-2015. Estimates are derived from ordinary least squares in specifications (1) to (5) and system GMM in (6). All specifications include time fixed effects, controls for lagged years of secondary schooling, and quality of economic institutions. Specification (2) includes controls for experience and experience squared; specification (3) includes the pre-tax, pre-transfer Gini coefficient; and specification (4) includes lagged controls for physical capital per worker and population health. Specifications in (5) and (6) account for country-specific growth trends by including country fixed effects. The panel GMM specification in (6) uses the first lag of the endogenous variables in the difference equation and the first difference of the endogenous variables in the level equation as instruments; standard errors in this specification are computed with the two-step procedure and corrected with respect to finite sample size (Windmeijer, 2005). Standard errors are clustered on the country level and reported in parentheses. Asterisks indicate significance levels: * $p<0.1 ;{ }^{* *} p<0.05 ; * \star p<0.01$. 
Table A8. Robustness: Life Expectancy at Birth

\begin{tabular}{|c|c|c|c|c|c|c|}
\hline \multirow[t]{2}{*}{ Dependent variable } & \multicolumn{6}{|c|}{ Growth rate of income per capita } \\
\hline & $\begin{array}{c}\text { Baseline } \\
\text { controls } \\
\text { (1) }\end{array}$ & $\begin{array}{c}\text { Including } \\
\text { working } \\
\text { experience } \\
(2)\end{array}$ & $\begin{array}{c}\text { Including } \\
\text { income } \\
\text { inequality } \\
(3)\end{array}$ & $\begin{array}{l}\text { Including } \\
\text { lagged } \\
\text { controls } \\
(4)\end{array}$ & $\begin{array}{l}\text { Country } \\
\text { growth } \\
\text { trends } \\
(5)\end{array}$ & $\begin{array}{c}\text { Panel } \\
\text { GMM } \\
(6)\end{array}$ \\
\hline Log income per capita $(t-1)$ & $\begin{array}{c}-0.068^{* * * *} \\
(0.009)\end{array}$ & $\begin{array}{c}-0.069^{* * * *} \\
(0.009)\end{array}$ & $\begin{array}{c}-0.069^{* * *} \\
(0.011)\end{array}$ & $\begin{array}{c}-0.157^{* * *} \\
(0.013)\end{array}$ & $\begin{array}{c}-0.266^{* * *} \\
(0.034)\end{array}$ & $\begin{array}{c}-0.065^{* * *} \\
(0.023)\end{array}$ \\
\hline Growth of capital per worker & $\begin{array}{c}0.346^{* * *} \\
(0.048)\end{array}$ & $\begin{array}{c}0.357^{* * *} \\
(0.047)\end{array}$ & $\begin{array}{c}0.286^{* * *} \\
(0.055)\end{array}$ & $\begin{array}{c}0.330^{* * *} \\
(0.058)\end{array}$ & $\begin{array}{c}0.260^{* * *} \\
(0.081)\end{array}$ & $\begin{array}{c}0.360^{* * *} \\
(0.052)\end{array}$ \\
\hline Change in life expectancy & $\begin{array}{c}0.015 * * * \\
(0.004)\end{array}$ & $\begin{array}{c}0.017^{* * * *} \\
(0.003)\end{array}$ & $\begin{array}{c}0.017^{* * * *} \\
(0.004)\end{array}$ & $\begin{array}{c}0.015 * * * \\
(0.004)\end{array}$ & $\begin{array}{c}0.009^{* *} \\
(0.004)\end{array}$ & $\begin{array}{c}0.015^{* * * *} \\
(0.004)\end{array}$ \\
\hline Change in secondary schooling & $\begin{array}{c}0.068^{* * *} \\
(0.024)\end{array}$ & $\begin{array}{c}0.065^{* * * *} \\
(0.024)\end{array}$ & $\begin{array}{c}0.057^{* *} \\
(0.023)\end{array}$ & $\begin{array}{c}0.028 \\
(0.024)\end{array}$ & $\begin{array}{l}0.049^{*} \\
(0.026)\end{array}$ & $\begin{array}{c}0.062^{* *} \\
(0.029)\end{array}$ \\
\hline $\begin{array}{l}\text { Growth of working-age population/ } \\
\text { total population }\end{array}$ & $\begin{array}{c}1.110^{* * * *} \\
(0.292)\end{array}$ & $\begin{array}{c}1.113^{* * * *} \\
(0.336)\end{array}$ & $\begin{array}{c}1.126^{* * * *} \\
(0.383)\end{array}$ & $\begin{array}{c}0.984^{* * * *} \\
(0.285)\end{array}$ & $\begin{array}{c}0.312 \\
(0.411)\end{array}$ & $\begin{array}{c}1.078 * * * \\
(0.339)\end{array}$ \\
\hline Countries & 133 & 131 & 131 & 133 & 133 & 133 \\
\hline Observations & 1020 & 948 & 731 & 1020 & 1020 & 1020 \\
\hline$R^{2}$ & 0.29 & 0.30 & - & 0.34 & 0.33 & - \\
\hline $\mathrm{AR}(2) p$-value & - & - & - & - & - & 0.11 \\
\hline Hansen $p$-value & - & - & - & - & - & 0.09 \\
\hline Diff.-in-Hansen $p$-value & - & - & - & - & - & 0.94 \\
\hline
\end{tabular}

Note: Estimation results for five-year panels of 133 countries over the period 1965-2015. Estimates are derived from ordinary least squares in specifications (1) to (5) and system GMM in (6). All specifications include time fixed effects, controls for lagged years of secondary schooling, and quality of economic institutions. Specification (2) includes controls for experience and experience squared; specification (3) includes the pre-tax, pre-transfer Gini coefficient; and specification (4) includes lagged controls for physical capital per worker, population health, and the size of the working-age population relative to the total population. Specifications in (5) and (6) account for country-specific growth trends by including country fixed effects. The panel GMM specification in (6) uses the first lag of the endogenous variables in the difference equation and the first difference of the endogenous variables in the level equation as instruments; standard errors in this specification are computed with the two-step procedure and corrected with respect to finite sample size (Windmeijer, 2005). Standard errors are clustered on the country level and reported in parentheses. Asterisks indicate significance levels: ${ }^{\star} p<0.1$; ${ }^{\star \star} p<0.05 ;{ }^{* \star \star} p<0.01$. 
Table A9. Robustness: Total Years of Schooling

\begin{tabular}{|c|c|c|c|c|c|c|}
\hline \multirow[t]{2}{*}{ Dependent variable } & \multicolumn{6}{|c|}{ Growth rate of income per capita } \\
\hline & $\begin{array}{c}\text { Baseline } \\
\text { controls } \\
\text { (1) }\end{array}$ & $\begin{array}{c}\text { Including } \\
\text { working } \\
\text { experience } \\
\text { (2) }\end{array}$ & $\begin{array}{c}\text { Including } \\
\text { income } \\
\text { inequality } \\
\text { (3) }\end{array}$ & $\begin{array}{l}\text { Including } \\
\text { lagged } \\
\text { controls } \\
\text { (4) }\end{array}$ & $\begin{array}{l}\text { Country } \\
\text { growth } \\
\text { trends } \\
(5)\end{array}$ & $\begin{array}{c}\text { Panel } \\
\text { GMM } \\
(6)\end{array}$ \\
\hline Log income per capita $(t-1)$ & $\begin{array}{c}-0.077^{* * *} * \\
(0.009)\end{array}$ & $\begin{array}{c}-0.080^{* * * *} \\
(0.009)\end{array}$ & $\begin{array}{c}-0.083^{* * *} \\
(0.012)\end{array}$ & $\begin{array}{c}-0.160^{* * *} \\
(0.013)\end{array}$ & $\begin{array}{c}-0.259 * * * \\
(0.033)\end{array}$ & $\begin{array}{c}-0.066^{* * *} \\
(0.023)\end{array}$ \\
\hline Growth of capital per worker & $\begin{array}{c}0.335^{* * *} \\
(0.049)\end{array}$ & $\begin{array}{c}0.346^{* * *} \\
(0.048)\end{array}$ & $\begin{array}{c}0.279^{* * *} \\
(0.056)\end{array}$ & $\begin{array}{c}0.338^{* * * *} \\
(0.058)\end{array}$ & $\begin{array}{c}0.243^{* * *} \\
(0.081)\end{array}$ & $\begin{array}{c}0.355^{* * * *} \\
(0.052)\end{array}$ \\
\hline Change in life expectancy & $\begin{array}{c}0.744^{* * *} \\
(0.250)\end{array}$ & $\begin{array}{c}0.964^{* * *} \\
(0.225)\end{array}$ & $\begin{array}{c}0.798 * * * \\
(0.294)\end{array}$ & $\begin{array}{c}0.721^{* * *} \\
(0.250)\end{array}$ & $\begin{array}{l}0.377^{*} \\
(0.219)\end{array}$ & $\begin{array}{c}0.692^{* * *} \\
(0.260)\end{array}$ \\
\hline Change in schooling & $\begin{array}{c}0.033^{* *} \\
(0.016)\end{array}$ & $\begin{array}{c}0.035^{* *} \\
(0.017)\end{array}$ & $\begin{array}{c}0.028 \\
(0.017)\end{array}$ & $\begin{array}{c}0.018 \\
(0.016)\end{array}$ & $\begin{array}{c}0.011 \\
(0.016)\end{array}$ & $\begin{array}{c}0.023 \\
(0.020)\end{array}$ \\
\hline $\begin{array}{l}\text { Growth of working-age population/ } \\
\text { total population }\end{array}$ & $\begin{array}{c}0.979^{* * *} \\
(0.301) \\
\end{array}$ & $\begin{array}{c}1.025^{* * *} \\
(0.336) \\
\end{array}$ & $\begin{array}{l}0.986^{* *} \\
(0.395)\end{array}$ & $\begin{array}{c}0.944^{* * *} \\
(0.288)\end{array}$ & $\begin{array}{c}0.183 \\
(0.418)\end{array}$ & $\begin{array}{l}0.992^{* *} \\
(0.397)\end{array}$ \\
\hline Countries & 133 & 131 & 131 & 133 & 133 & 133 \\
\hline Observations & 1020 & 948 & 731 & 1020 & 1020 & 1020 \\
\hline$R^{2}$ & 0.29 & 0.30 & - & 0.34 & 0.33 & - \\
\hline $\mathrm{AR}(2) p$-value & - & - & - & - & - & 0.11 \\
\hline Hansen $p$-value & - & - & - & - & - & 0.16 \\
\hline Diff.-in-Hansen $p$-value & - & - & - & - & - & 0.93 \\
\hline
\end{tabular}

Note: Estimation results for five-year panels of 133 countries over the period 1965-2015. Estimates are derived from ordinary least squares in specifications (1) to (5) and system GMM in (6). All specifications include time fixed effects, controls for lagged years of schooling, and quality of economic institutions. Specification (2) includes controls for experience and experience squared; specification (3) includes the pretax, pre-transfer Gini coefficient; and specification (4) includes lagged controls for physical capital per worker, population health, and the size of the working-age population relative to the total population. Specifications in (5) and (6) account for country-specific growth trends by including country fixed effects. The panel GMM specification in (6) uses the first lag of the endogenous variables in the difference equation and the first difference of the endogenous variables in the level equation as instruments; standard errors in this specification are computed with the two-step procedure and corrected with respect to finite sample size (Windmeijer, 2005). Standard errors are clustered on the country level and reported in parentheses. Asterisks indicate significance levels: * $p<0.1$; ${ }^{* \star} p<0.05 ;{ }^{* \star} p<0.01$. 
Table A10. Robustness: Alternative Panel GMM Specifications

\begin{tabular}{lcccc}
\hline Dependent variable & \multicolumn{3}{c}{ Growth rate of income per capita } \\
\cline { 2 - 5 } & $\begin{array}{c}\text { System } \\
\text { GMM }\end{array}$ & $\begin{array}{c}\text { Forward } \\
\text { orthogonal } \\
\text { deviations }\end{array}$ & $\begin{array}{c}\text { Instrument with } \\
\text { second rather } \\
\text { than first lag }\end{array}$ & $\begin{array}{c}\text { Instrument } \\
\text { set collapsed }\end{array}$ \\
& $(1)$ & $(2)$ & $(3)$ & $(4)$ \\
\hline Log income per capita $(t-1)$ & $-0.060^{* * *}$ & $-0.049^{* * *}$ & $-0.107^{* * *}$ & $-0.093^{*}$ \\
& $(0.023)$ & $(0.016)$ & $(0.022)$ & $(0.051)$ \\
Growth of capital per worker & $0.364^{* * *}$ & $0.367^{* * *}$ & $0.229^{* *}$ & $0.360^{* * *}$ \\
Change in adult survival & $(0.051)$ & $(0.053)$ & $(0.095)$ & $(0.071)$ \\
& $0.653^{* *}$ & $0.592^{* *}$ & $0.850^{* *}$ & 0.524 \\
Change in secondary schooling & $(0.271)$ & $(0.283)$ & $(0.397)$ & $(0.338)$ \\
& $0.062^{* *}$ & $0.057^{* *}$ & 0.058 & 0.069 \\
Growth of working-age population/ & $(0.028)$ & $(0.026)$ & $(0.054)$ & $(0.044)$ \\
total population & $0.968^{* * *}$ & $0.977^{* * *}$ & $0.843^{* *}$ & 0.732 \\
Countries & $(0.361)$ & $(0.312)$ & $(0.403)$ & $(0.467)$ \\
Observations & 133 & 133 & 133 & 133 \\
Instruments & 1020 & 1020 & 1020 & 1020 \\
AR(2) $p$-value & 106 & 107 & 104 & 60 \\
Hansen $p$-value & 0.10 & 0.09 & 0.11 & 0.11 \\
Diff.-in-Hansen $p$-value & 0.15 & 0.18 & 0.10 & 0.00 \\
\hline
\end{tabular}

Note: Estimation results for five-year panels of 133 countries over the period 1965-2015. Estimates are derived from system GMM. All specifications include time fixed effects, controls for lagged years of secondary schooling, and the quality of economic institutions. Country fixed effects are removed using forward orthogonal deviations in (2) and using first differences. All specifications instrument lagged log income per capita, the growth rate of physical capital per worker, the change in adult survival, the change in secondary schooling, and lagged secondary schooling. Endogenous variables are instrumented with their first lag except for specification (3), in which they are instrumented with their second lag instead. In (4), the lag count is limited by collapsing the instrument set. Standard errors in GMM are computed with the two-step procedure and corrected with respect to finite sample size (Windmeijer, 2005). Standard errors are clustered on the country level and reported in parentheses. Asterisks indicate significance levels: ${ }^{*} p<0.1 ;{ }^{* \star} p<0.05 ;{ }^{* \star \star} p<0.01$. 
Table B1. Coding Description

This table describes coding choices for countries in which compulsory schooling laws differ by schooling type or target group and countries that experienced longer spells of turbulence and civil war. This list contains all countries for which information on compulsory schooling was available and thus even those that do not enter the estimation sample. The sources for these descriptions are United Nations Educational, Scientific and Cultural Organization (UNESCO) yearbooks from 1963-1997 (UNESCO, 1963-1997) and UNESCO (2017).

Albania: UNESCO yearbooks report four plus an additional three years of compulsory schooling for 1963 and 1964 . From 1965 to 1967, four plus an additional four years of compulsory schooling are reported. We code these as seven and eight years of schooling because '[f]our years' schooling is compulsory for all children; a second period of three (four) years is compulsory for children in towns and villages where a seven-grade (eight-grade) school is available" (UNESCO, 19631968).

Andorra: Andorra's education system splits into French and Spanish schools. However, because both schooling systems differ in terms of compulsory schooling, we follow UNESCO's convention and code values as missing until 1977. Afterward, both schools require a minimum of 10 years of schooling so that we code a value of 10 .

Angola: "The school system in the Portuguese Overseas Provinces forms part of the general pattern of Portuguese education. It is consequently the same as in metropolitan territory, but not all the levels and types of education provided in Portugal are to be found overseas" (UNESCO, 1964-1967). Therefore, we assume that for the years 1964 to 1967, compulsory schooling amounts to four years as is the case for Portugal.

Argentina: In 1972, compulsory schooling takes a value of eight years, while before and after compulsory schooling is consistently reported with seven years. Because the structure of the education system did not change in 1972, we code a value of seven years.

Australia: For 1963 and 1964, UNESCO yearbooks report eight to 10 years of compulsory schooling, varying by state. We take the figure of New South Wales, the most densely populated state, and thus code nine years. From 1968 onward, the yearbooks report values between nine and 11 years, varying by state or whether kindergarten counts toward primary education. We code 10 years of compulsory schooling. This figure is consistent with more recent data (UNESCO, 2017). Moreover, the number reflects average compulsory schooling.

Bahrain: For 1971 and 1972, eight years of compulsory schooling are reported. However, change "will be applied in 1973/1974" (UNESCO, 1971). Following the value of the preceding years, we code a value of zero. For 1987 to 1993, zero compulsory schooling is reported. This figure contrasts with the high values before and after. We thus code a missing rather than a zero value. Based on the age range, 12 years of compulsory schooling are reported for 1995 to 1997. However, the compulsory program only contains six years of primary schooling with a general academic curriculum combined with religious instruction, which continues to nine years. Correspondingly, we code nine instead of 12 years for 1995 to 1997.

Barbados: There is no compulsory schooling from 1963 to 1967; however, the value for 1966 is missing. We impute this value to be zero. For the years 1995 to 1997, UNESCO yearbooks report 12 years of compulsory schooling instead of 11 in preceding and subsequent periods.

Belgium: In 1985 and 1986, UNESCO yearbooks report eight and nine years of compulsory schooling. Based on the preceding years and the age range, nine years of compulsory schooling are implausible, however. Therefore, we code eight years in 1985 and 1986.

Benin: After independence in 1960, there was a longer spell of political turbulence. In particular, several changes in power occurred at the beginning of the 1970s. According to the UNESCO yearbooks, compulsory schooling amounts to six years until 1970, zero years from 1971 to 1974, and seven years from 1975 onward. Due to the unstable nature of the government, the exact role of compulsory schooling and whether it was enforced is unclear. Therefore, we decided to code the years 1971 to 1974 as missing rather than a clean zero.

Brazil: For 1963 and 1964, UNESCO yearbooks report compulsory schooling values of four and five years. From 1965 onward, the level remains consistently at four years. Because Brazil follows the Portuguese education system, we code a value of four for 1963 and 1964.

Brunei: For 1995 to 1997, UNESCO yearbooks report compulsory schooling levels of 12 years. These contrast nine years of compulsory schooling before and after. Because neither the education system nor the age range of compulsory schooling changed during this period, we code nine instead of 12 years.

Cameroon: Historically, the education system consisted of French schools in the eastern and British schools in the western part of Cameroon. In 1976, the British system was adopted in the entire country. We use the British system's compulsory schooling regulations throughout all periods. UNESCO yearbooks list eight years of compulsory schooling in 1969 and 1970. Given the subsequent period without any compulsory schooling, enforcement of this regulation is unlikely. We thus code a zero value for 1969 and 1970. 
Canada: Compulsory schooling "[...] figures vary slightly from one Province to another" (UNESCO, 1963). Values range from seven to 10 years between 1963 and 1968 and eight to 10 years between 1969 and 1994 . We take a slightly conservative view and code a value of eight years for 1963-1968 and nine years for 1969-1994.

Cape Verde: "The school system in the Portuguese Overseas Provinces forms part of the general pattern of Portuguese education. It is consequently the same as in metropolitan territory, but not all the levels and types of education provided in Portugal are to be found overseas" (UNESCO, 1964-1967). Therefore, we assume that for 1964 to 1967, compulsory schooling amounts to four years as is the case for Portugal.

Czech Republic and Slovakia: We use compulsory schooling regulations of former Czechoslovakia for both countries prior to 1994.

Egypt: For 1989 to 1991, UNESCO yearbooks report nine years of compulsory education. However, these figures are implausible given five years of primary and three years of lower secondary education. Therefore, we code eight rather than nine years. For 1995 and 1996, the yearbooks report five years of compulsory schooling. This figure does not reflect lower secondary education, which is also compulsory since the educational reforms in the early 1990s. Hence, we set the corresponding value to eight years instead of five.

Eswatini: In the early years until 1965, the education system consisted of European, African, and Eurafrican schools. Because education was compulsory only at European schools, which were abolished from 1966 onward, and not for the other school types, we code a value of zero.

Fiji: Between 1975 and 1997, UNESCO yearbooks report zero years of compulsory schooling in contrast to eight years from 1963 to 1974. We follow the UNESCO's convention, which codes missing values of compulsory schooling between 1998 and 2015 (UNESCO, 2017). Thus, we code missing values for 1975 to 1997.

Finland: For 1967, 1971, and 1972, UNESCO yearbooks report eight instead of formerly nine years of compulsory schooling. Based on the age range and structure of the education system, these shifts seem implausible. Thus, we code nine year of compulsory schooling.

Germany: Figures are based on West Germany prior to 1990. We code 12 rather than nine years of compulsory schooling in 1968-1970 and 1973-1988. This coding includes nine years of compulsory schooling plus an additional three years of "[...] part time vocational education" (UNESCO, 1973).

Guinea: In 1971/1972, compulsory schooling increased from eight to 12 years before it dropped again back to eight years in 1973. Throughout this period, the overall structure of the education system remained unaltered. The only detectable change was the range of compulsory schooling from ages 7-15 to 7-22, which is implausible compared with other countries and Guinea's legal age. Therefore, compulsory schooling is coded to remain at eight years instead of 12.

Guinea-Bissau: For 1981 and 1982, UNESCO yearbooks report seven years of compulsory schooling in contrast to six years in preceding and subsequent periods. Because the education system remained unaltered during these years, this change seems implausible. Hence, we code six rather than seven years.

Guyana: Throughout 1963 to 1997, compulsory schooling takes a value of eight years with the exception of 1981 and 1982 (nine years), 1983 (six years), and 1995 to 1997 (10 years). However, the shifts are inconsistent with the relative stability of the education system between 1980 and 1984 and the age range of compulsory schooling from ages six to 14 for 1995 to 1997 . We thus code eight years over the entire period.

India: In 1971 and 1972, the UNESCO yearbooks report various levels of compulsory schooling. In the years thereafter, only a uniform level of five years is reported. This change is justified by the fact that "[t]his information pertains to the majority of states" (UNESCO, 1975). Therefore, we also code a value of five years for 1971 and 1972.

Indonesia: In 1973 and 1974, UNESCO yearbooks report zero values for compulsory schooling. These figures contrast six years of compulsory schooling before and thereafter. Moreover, the education system remained unaltered during this period. Hence, we code a value of six instead of zero years.

Iran: For 1966, 1967, 1973, and 1974, UNESCO yearbooks report five years of compulsory schooling in contrast to six years in preceding and intermediate periods. However, these figures seem implausible because the education system remained unaltered during this period. Therefore, we code six rather than five years.

Iraq: UNESCO yearbooks consistently report six years of compulsory schooling. In 1983, however, five years are reported although the educational structure did not change. We code six instead of five years. Moreover, compulsory schooling is missing in 1973 and 1974. Because the education system remained unaltered, we set the value to six years-the same as in the preceding and following years. 
Israel: Between 1981 and 1987, UNESCO yearbooks report nine years of compulsory schooling in contrast to 11 years in preceding and subsequent periods. Moreover, this figure seems implausible given the age range from five to 15. Hence, we code 11 instead of nine years for this period.

Jordan: According to the UNESCO yearbooks, compulsory schooling increased from six to nine years in 1964 based on a widening of the age range. However, this increase is not observed in 1965 where the age range is again six years. Therefore, we code six instead of nine years.

Kiribati and Tuvalu: Until 1976, the islands were a British protectorate under the name Gilbert and Ellice Islands. We thus use compulsory schooling of the former protectorate for both Kiribati and Tuvalu. For the years 1975 to 1980, during which the islands became independent, we code missing instead of the reported zero values. For the years 1985 and 1986 , UNESCO yearbooks report five years of schooling in contrast to nine years in the preceding and subsequent periods. Because the education system remained unaltered during this time, we code nine instead of five years.

Kuwait: For 1982 and 1983, UNESCO yearbooks report four rather than eight years as in preceding and subsequent periods. Because the education system remained unaltered during this period, we code eight instead of four years.

Laos: For the years 1990 to 1994, UNESCO yearbooks report eight rather than five years of compulsory schooling as in preceding and subsequent periods. Because the education system with five years of compulsory primary schooling remained unaltered during this period, we code five instead of eight years.

Lebanon: Throughout 1963 to 1997, compulsory schooling is consistently zero years, except for 1971 where UNESCO yearbooks report a value of 12 . Given the overall trend, this value seems implausible so that we code zero years.

Lesotho: The UNESCO yearbooks report compulsory schooling of eight years for the former British Crown colony Basutoland in 1964 and 1965. However, there was no compulsory schooling for the independent state of Lesotho between 1966 and 1984. Moreover, the yearbooks also report a value of zero for the colony in 1963. We thus set the value for compulsory schooling to zero for 1964 and 1965.

Malawi: For 1963 to 1965, UNESCO yearbooks report eight years of compulsory schooling based on the English schools in the former British colony. From 1966 onward, zero years of schooling are reported. Because Malawi became independent in 1964, eight years of compulsory schooling seem implausible. Hence, we code zero rather eight years.

Malaysia: From 1968 to 1984, UNESCO yearbooks report six years of compulsory schooling for some and zero or missing values for other regions. Because there is no compulsory schooling in the most populous regions, we code zero years from 1968 to 1984.

Malta: In 1986 and 1987, UNESCO yearbooks report 12 years of compulsory schooling. Based on the stable education system, the age range, and subsequent values, these figures seem implausible. We code 10 instead of 12 years.

Mauritius: For 1981 to 1983, UNESCO yearbooks report eight years of compulsory schooling rather than seven years as in preceding and subsequent years. Because the education system remained unaltered during this period, we code seven rather than eight years. Between 1987 and 1994, figures for compulsory schooling drop to zero. However, these values seem implausible because the education system did not change in this period either. We code missing instead of zero values.

Monaco: For 1973 and 1974, UNESCO yearbooks report 11 years of compulsory schooling rather than 10 years as before and after. Because the education system remained unaltered during this period, we code 10 rather than 11 years.

Mozambique: "The school system in the Portuguese Overseas Provinces forms part of the general pattern of Portuguese education. It is consequently the same as in metropolitan territory, but not all the levels and types of education provided in Portugal are to be found overseas" (UNESCO, 1964-1967). Therefore, we assume that for 1964 to 1967, compulsory schooling amounts to four years as is the case for Portugal.

Nauru: For 1963 to 1970, UNESCO yearbooks report nine years of compulsory schooling for European and 10 years for Nauruan schools. We code a value of 10 years.

Nepal: Historically, the Nepalese education system consisted of English and Sanskrit schools. Until 1967, there was no compulsory schooling for either of these types of schools. Beginning in 1968, the English school system prescribed five years of schooling while attendance at Sanskrit schools was not compulsory. Following the UNESCO's convention to document compulsory schooling based on the English system from 1973 onward (UNESCO, 1973), we code five years of compulsory schooling.

New Zealand: For 1994 to 1997, UNESCO yearbooks report 11 years of compulsory schooling. However, the education system consists of six years of primary and four years of lower secondary schooling. For this reason, we code 10 rather than 11 years. This coding choice is consistent with preceding and subsequent periods and the stability of the education system overall. 
Niger: For 1973 to 1979, the UNESCO yearbooks report compulsory schooling of 12/13 years rather than eight years as in the preceding and subsequent periods. This substantial change is not reflected in a corresponding transformation of the education system and only represents shifts in the age range for compulsory schooling. Therefore, this extreme increase seems implausible so that we code compulsory schooling to remain at eight years throughout 1973 to 1979.

Norway: From 1968 to 1970, values of seven and nine years are reported because "[a] law passed in 1968 extended compulsory education from seven to nine years. This has been applied in most municipalities" (UNESCO, 1968).

Philippines: In 1963 and 1964, a missing value of compulsory schooling is reported. However, we decided to code a zero value because "[i]n implementation of Republic Act No. 1124, Department Order No. 1, s. 1957, Article 2 states that elementary education shall ultimately be made available for all children between 7 and 13 years" (UNESCO, 1963). Hence, compulsory schooling was not yet implemented in 1963 and 1964.

Poland: Between 1963 and 1970, UNESCO yearbooks report various values of compulsory schooling. We take a conservative view and code 1963 and 1964 with a value of seven years and 1965 to 1970 with a value of eight years.

Republic of Congo: For the period 1973 and 1974, compulsory schooling dropped from an initial value of 10 to six years. From 1975 onward, compulsory schooling reverted back to a value of 10 years. Throughout this entire time, compulsory schooling age ranged from six to 16 years for boys and six to 17 years for girls. Therefore, we also code a value of 10 years for 1973 and 1974.

Romania: For 1963 and 1964, UNESCO yearbooks report seven or eight years of compulsory schooling. In subsequent years, educational regulations prescribe eight years of compulsory schooling. Based on this stability in the education system, we set values to eight years for 1963 and 1964.

Saint Lucia: For 1985 and 1986, UNESCO yearbooks report 11 years of compulsory education rather than 10 years as in preceding and subsequent periods. Because the structure of the education system with seven years of primary and three years of lower secondary schooling did not change during these years, this shifts seems implausible. Hence, we code 10 rather than 11 years.

Sao Tome and Principe: "The school system in the Portuguese Overseas Provinces forms part of the general pattern of Portuguese education. It is consequently the same as in metropolitan territory, but not all the levels and types of education provided in Portugal are to be found overseas" (UNESCO, 1964-1967). Therefore, we assume that for the years 1964 to 1967 , compulsory schooling amounts to four years as is the case for Portugal.

Senegal: UNESCO yearbooks report seven years of compulsory education for 1971 and 1972 and six years for 1973 and 1974. However, compulsory primary education corresponded only to six and five years. Therefore, we code six and five years rather than seven and six.

Singapore: Compulsory schooling was only introduced in 2003. Hence, we code one missing value as zero before 2003.

South Africa: Between 1963 and 1984, UNESCO yearbooks report seven and nine years of compulsory schooling, varying by state and race. We code seven years of schooling as the corresponding figure for the black population, which constitutes approximately 80 percent of the total population.

Sri Lanka: From 1995 to 1997, UNESCO yearbooks report 11 years of compulsory schooling rather than 10 years as beforehand. Based on the age limits that remained unaltered over this period, we code 10 instead of 11 years.

St. Vincent and The Grenadines: UNESCO yearbooks report 10 years of compulsory schooling for 1968-1974 and 19781985 and zero years for 1963-1967, 1975-1977, and 1986-1995. Between 1996 and 2004, no values are reported. The overall structure of the education system did not change substantially throughout all these periods so that large shifts in compulsory schooling appear implausible. We thus code values for 1963-1967, 1975-1977, and 1986-1995 to be missing rather than zero.

Suriname: UNESCO yearbooks report 11 years of compulsory schooling for the period 1995 to 1997 . This figure stands in stark contrast to only six years before and after. Because the education system with six years of compulsory primary schooling remained unaltered during these years, we code six instead of 11 years.

Switzerland: According to the UNESCO yearbooks, compulsory schooling varies between seven and nine years across Swiss cantons from 1963 to 1997 . In some cantons, students are additionally required to take up at least two years of "complementary part-time schooling" (UNESCO, 1963). Hence, the reported figures are likely too low. Thus, we follow the convention of UNESCO reports from 1975 to 1981 and code nine years of compulsory schooling throughout the entire period.

Thailand: In 1963 and 1964, UNESCO yearbooks report between four and seven years of compulsory schooling. Based on the age range and subsequent values, we code both observations as seven. 
Tonga: For 1995 to 1997, UNESCO yearbooks report eight years of compulsory schooling. However, this figure seems implausible compared with six years in preceding and subsequent periods. Moreover, the education system remained unaltered during these years. Hence, we code six rather than eight years. For 2012 to 2015, UNESCO (2017) reports eight and then 15 years of compulsory schooling. These figures are implausible because only primary education, which requires six years of schooling, is compulsory in Tonga. Therefore, we also code six years of compulsory schooling for 2012 to 2015.

Trinidad and Tobago: In 1973 and 1974, 10 years of compulsory schooling is reported. Before 1973 and after 1974, this figure corresponds to seven years. Because only primary schooling is compulsory with a standard duration of seven years given entry ages for primary and secondary schooling, we code a value of seven for 1973 and 1974.

Turkey: Between 1965 and 1967, eight years of compulsory schooling is reported. However, only five years of primary schooling were compulsory. In line with preceding and subsequent periods, we thus code five years of compulsory schooling.

Tunisia: From 1968 to 1981, UNESCO yearbooks report six years of compulsory schooling. For 1982 and 1983, no values are reported. From 1984 onward, compulsory schooling is documented with a value of zero until 1992. The yearbooks show 11 years of compulsory schooling for 1993/1994 and nine years from 1995 onward. The education system consists of six years of primary schooling, three years of lower secondary schooling, and a further four years of upper secondary schooling. This structure is maintained throughout 1981 to 1995. Because zero values are implausible, we code them as missing. For 1993 and 1994, we set compulsory schooling to nine instead of 11 years.

United States: For the years 1963 to 1997, UNESCO yearbooks present values ranging from 10 to 12 years for the United States. Minimum compulsory schooling corresponds to 10 years, formally from age six to 16 . Some states require students to remain in school until coming of age, implying two further years. However, there are also exemption regulations for religious groups and homeschooling. We take a conservative view and set the compulsory schooling thus to the minimum value of 10 years, which all states fulfill.

Vanuatu: Historically, the education system consists of English and French schools. Compulsory schooling years refer to regulations with respect to English schools.

Yemen: Figures are based on compulsory schooling of the former Arab Republic of Yemen and the Republic of Yemen.

Zambia: For 1963 to 1966, UNESCO yearbooks report compulsory schooling of eight years with zero years from 1967 onward. Because "[e]ducation is compulsory in certain areas only" (UNESCO, 1963-1966), we code the years 1963 to 1966 as zero.

Azerbaijan, Armenia, Belarus, Estonia, Georgia, Kazakhstan, Kyrgyzstan, Latvia, Lithuania, Moldova, Russia, Tajikistan, Turkmenistan, Ukraine, Uzbekistan: Prior to 1992, we code compulsory schooling according to the values of the former Soviet Union. Between 1963 and 1966, UNESCO yearbooks report eight and nine years of compulsory schooling. Because primary schooling comprises only eight grades, we code eight rather than nine years.

Bosnia and Herzegovina, Croatia, Macedonia, Montenegro, Serbia, Slovenia: Prior to 1993, we code compulsory schooling according to values of former Yugoslavia. Figures of Serbia and Montenegro are taken from the Federal Republic of Yugoslavia for 1993 to 1997. 